\title{
INDENTURE SECURITIES AND THE BARKLEY BILL
}

\author{
By TALCOTT M. BANKS, JR. $\dagger$
}

THE sale to the public of corporate obligations issued under indentures of trust ${ }^{1}$ has been one of the chief means by which American commerce and industry have financed their extraordinary growth. The practical success of this method and the vitality of the interests which it has served have carried it through a century of development with remarkably little attention to the accompanying law. In consequence, when a period of critical examination suddenly arrived, the accumulation of faults in the practice of this mode of financing was exposed against a background of legal uncertainties. The confusion in precedents has encouraged proponents of change to search for comprehensive remedies, and in the resulting discussion the simple question of how to improve indenture financing, without impairing its utility, has at times been obscured.

The general re-examination of the subject of corporate trust indentures was stimulated by the publication of a vigorous report of the Securities and Exchange Commission. The Commission, in the course of its investigation of protective and reorganization committees, had studied the corporate indenture trustee, and of its series of reports Part VI, transmitted to Congress on June 18, 1936, ${ }^{2}$ dealt with corporate indentures and concluded with a strong recommendation for specific legislation. This recommendation was carried out in the Barkley Bill, ${ }^{3}$ introduced in the Senate May 6, 1937.

i Member of the Massachusetts Bar.

1. Indenture securities in the United States are popularly classificd as "bonds" (long-term secured), "debentures" (long-term unsecured) and "notes" (short-term, either secured or unsecured). These names should not, however, be relied upon as esact definitions, for variations are not infrequent, such as debentures being secured in various ways. As ordinarily the issuer or obligor is a corporation, and the usual security is a mortgage, the term "corporate mortgage" has been widely adopted to refer to the instrument under which indenture securities are issued.

In England the term "debenture" is used generally to include all forms of bonds. P $P_{\Lambda L}$ aIER's COMIPANy LAW (14th ed. 1930) 300 ff. Although the trust concept is peculiar to the common law, financing by indenture securities has appeared in some civil law jurisdictions: Nussbaum, Sociological and Comparatize Aspects of the Trist (1938) 38 CoL. L. Rev. 408, 418, 419, 429-430; see Zahn, The Trustee in German-American Industrial Loans (1932) 12 B. U. L. REv. 187, 428.

2. This report, and six others already published, are based on the investigation of protective and reorganization committees, authorized by $\S 211$ of the Securities Exchange Act of 1934. 48 Stat. 881, 15 U. S. C., \$78 (1934). Part VI will hereafter be referred to as "the Report."

3. Originally S.2344, 75th Cong., 1st Sess. (1937); H. R. 10292, 75th Cong., 3d Sess. (1938). The measure was reintroduced in both the Senate and the House of Representatives of the 76th Congress on January 10, 1939, and is now numbered S. 477 and H. R. 2191, 76th Cong., 1st Sess. (1939). 
Prepared under the auspices of the Securities and Exchange Commission, the Barkley Bill represents the first attempt to solve the problems of the present-day corporate indenture by national legislation. Although final adjournment of the Seventy-Fifth Congress came before the bill was debated in either chamber, it was extensively discussed in committee hearings in both the Senate and the House, ${ }^{4}$ and was reported favorably to the Senate..$^{5}$ As it has recently been introduced again, it is now before the Seventy-Sixth Congress for its consideration. Since the Barkley Bill touches every contemporary problem of corporate indenture financing, this article will be devoted primarily to the consideration of that measure in its setting.

\section{History of the Corporate Indenture}

A summary review of the development of indenture securities will serve to illustrate their unique character. ${ }^{6}$ Indentures have been used as a basis for the issuance of securities in America for at least a hundred years, ${ }^{7}$ and with the growth and extension of canals and railroads in the nineteenth century this method of financing was employed with increasing frequency in their construction. ${ }^{8}$

The early instances are of more than historical interest, for they demonstrate the fundamentals of the method and the need which it was devised to meet. These transportation agencies at first were highly spectlative ventures, with doubtful and fluctuating credit. ${ }^{\circ}$ Construction or extension

4. See infra note 68 .

5. Ibid.

6. For details on the history of the modern indenture see Jones, THE LAW of Railroad axd Other Corporate Securities (1st ed. 1879) ; Short, The law of Raliway Bonds AND MoRTgages (1897); Stetson, Preparation of Corparate Bonds, Mortgages, Collateral Trusts and Debenture Indentures, in SoMe LignL Punses of Corporate Financing, Reorganization and Regulation (1917); Page and Gates, The Work of Corporate Trust Departarents (1926); Smith, The Devezotinint of Trust Companies in the United States (1928); 2 Bogert, The Law of Trusts and Trustees (1935) \$246; McClelland and Fisher, Law of Corporate Montange Bond Issues (1937); Chaplin, The Story of Mortgage Laze (1890) 4 HARv. L. Rev. 1; Smith, A Forgotten Chapter in the Early History of the Corporate Trust Decd (1927) 61 Axr. L. REv. 900; Posner, Liability of the Trustee under the Corporatc Indenture (1928) 42 Harv. L. Rev. 198; Draper, A Historical Introduction to the Corporate Mortgage (1930) 2 Rocky Mr. L. Rev. 71. See also an essay on the English practice of mortgaging tolls to finance the construction of toll roads in (1827) $4 \mathrm{LAW}$ TrAcrs 97.

7. What is currently accepted as the earliest example is the "Dutch loan" of The Morris Canal and Banking Company, which conveyed its property to an Amsterdam merchant in trust to secure a loan of $\$ 750,000$ made by several individuals. See Willins: v. The Morris Canal and Banking Company, 4 N. J. Eq. 377 (1843) ; REport of A Jornt Conmittee of the Directors and Stockholders of The Morris Canal and Banking CoMpany (1832).

8. See Draper, supra note 6 , at 77-86.

9. The original Morris Canal stock issue of $\$ 1,000,000$ in 1825 was over-subserihed more than seven times and the stock soon sold at nearly a 20 per cent premium. Within 
required the investment of larger sums than single institutions or individuals could or would risk. Municipalities, counties, states and the Federal government subsidized these enterprises in various ways ${ }_{3}^{10}$ and speculators supplied funds in large amounts, but a means was needed to tap the resources of the conservative investing public, which promises of high interest rates and astonishing appreciation of capital could not attract. The obvious and familiar instrument for this end was the mortgage, but a mortgage split among a number of mortgagees involved undesirable technical difficulties in transfer and foreclosure, and it lacked the inducement of negotiability. ${ }^{11}$ To avoid these troubles, and to enable the issuer to offer investors a form of security which would approach if not at once attain a negotiable quality, a plan was adopted whereby the mortgage ran to a single individual, to be held by him as security for the notes which subscribers would receive. This individual had two functions: before default he was merely a repository of the noteholders' interest in the security, which he held in escrow or as a stakeholder; after default, if foreclosure was necessary, he was the investors' agent to effect it. The first duty was purely passire, the second active but still ministerial; neither corresponded with the duty of a trustee as it is understood today. ${ }^{12}$ The position needed only a reliable person, and little regard was paid to conflicts of interest, as is shown by the common practice in early canal and railroad mortgages of having as trustee an official of the issuing company. ${ }^{13}$

a few years the stock sold at one-sixth of that price. The Lehigh Canal Company experienced similar vicissitudes. See Report of the Presinent asd Directons of tae Morris Canal and Batking Conipant to the Stockholders for tite Year 1833.

10. See Stetson, supra note 6 , at 5 ; Draper, supra note 6 , at 78 . The shift from governmental financing to financing by private parties is illustrated in the instance of the Chesapeake and Ohio Canal. Swift axd H.ile, Report on the Present State of the Chesapeake and Ohio Canal (1846); Davis and Hale, loa: fur the Coarrletio: of the Chesapeake and Ohio Canal (1847); Report to tue Stocknoldens on the Conpletion of the Chesapeike and OHio Canal (1S51); Wand, The Eirly Devaloparent of the Chesapeake and Ohto Canal Project, Johas Hopki:s Uaiversity Studies ox Historical axd Political Science, Series XVII, Nos. 9, 10, 11 (1899).

11. Afortgages running to the individual bondholders have, however, been employed. King v. Tuscumbia, C. \& D. R. R., 7 Pa. L. J. 166, 14 Fed. Cas. No. $780 S$ (N. D. Ala. 1846); Railroad Company v. Orr, IS IVall. 471 (U. S. 1873). Another compliation in this method would be encountered when the mortgagees were not all ascertained, either in number or in name, at the time of the original transaction.

12. In the case involving the Morris Canal deed of 1830 this individual was described as "the agent and trustee of the several subscribers." The opinion states that "he was the agent of the company in making the loan, and is declared by the mortgage to be the representative of the lenders also." Willink v. The ALorris Canal and Banling Company, 4 N. J. Eq. 377, 381, 396 (1843). The phrase "nominal trustee" was used in an early text. Joxes, MIortgages (2d ed. 1879) $\$ 13 \$ 3$.

13. Stetson, supra note 6 , at 6; Draper, supra note 6 , at 84; Posner, The Trustec and the Trust Indenture, a Further Study (1937) 46 Y.aLE L. J. 737, 738. Sce infra note 28; Ashuelot Railroad Company v. Elliott, 57 N. H. 397 (1874). 
The character of the office of trustee under a corporate indenture was stamped upon it in these early years, and although it has puzzled courts and evaded satisfactory definition to the present time it has never been essentially changed. ${ }^{14}$ The reason for this constancy is that it suits the business need. It is a great convenience to have an intermediary in exactly this position, and although the development and tremendous complication of the indenture have blurred the outline of the trustee's functions, no fundamental revision of them has apparently ever become imperative to preserve or increase the inclenture's utility.

In considering the development of the corporate indenture it will be helpful to separate the interests involved. First is the interest of the issuer or obligor. The entire transaction is designed for its benefit. ${ }^{15}$ In return for encumbering its property, it obtains the money it needs. If this method of financing should be so altered as to become unworkable, ${ }^{10}$ it alone would suffer directly. Second is the interest of the investor. His primary care is, of course, that the issuer should protect his capital and income by meeting its interest and principal obligations faithfully and otherwise keeping its credit good; beyond that his sole concern is in the fullest possible realization upon the security if irremediable defatilt occurs. Finally, there is that vague, pervading presence, the public interest, in the name of which a great deal may be done or undone, but which here may reasonably be confined to keeping the indenture method from becoming either a vehicle for fraud or oppressive and unfair, in fact or potentially, to either of the principal parties. ${ }^{17}$

Each significant innovation in the development of the corporate trust indenture manifests a single purpose, to increase the efficacy of the instrument in view of the main end of raising funds. Sometimes the interest of the issuer is particularly evident, as in the various steps in which additional assets, present and prospective, were turned to use as security, until every conceivable form of property, tangible and intangible. presently owned or to be acquired, came to be covered by the indenture. More usually the regard is clearly for the interest of the investor, as in

14. The relatively little change in the nature of the trustce's functions, before and after default, and the controversy over his legal position, can be traced in indentures, cases and early treatises. See supra notes 6,7 and 12 , infra notes $24,25,26$. See espucially Jones, op. cit. supra note 6 , at $\$ \$ 357,360$; ShorT, op. cit. supra note 6 , at $\$ 258$.

15. In Gilfillan v. Union Canal Co., 109 U. S. 401, 403-404 (1883), Waite, C. I.. said: "The mortgage, with the issue and distribution of bonds under it, creates a trust, of which the selected mortgagee, or his duly constituted successor, is the trustee, and the bondholders primarily, and the stockholders ultimately, the beneficiaries." If trust analo. gies are required, this suggests the interesting, although inexact, comparison of a trustee of a personal trust having both life beneficiaries and remaindermen.

16. That is, if the flotation of indenture securities becomes so expensive or difficult as to be of little use to business.

17. The others directly concerned are the trustee, who should have no personal interest as such, and the investment banker, whose interest is secondary or representative. 
the acceleration clause; provisions restricting the release and substitution of security, the issue of additional bonds and the application of proceeds; requirements for recordation; sinking fund arrangements; and the great elaboration of the provisions defining rights of entry, foreclosure and sale. The repelling complexity of the modern indenture is in large degree the result of attempts to make it attractive to the investing public through the addition of safeguards. ${ }^{18}$ As the property forming the eventual security increased in size and variety, its conservation and maintenance became increasingly difficult to assure. Intricate covenants obliging the issuer to protect the value of the security came into general use, and the method of requiring certificates was adopted as a practicable means of checking performance. The advantages of foreclosure and the possibility of profitable sale diminished or vanished, to be inadequately replaced by the right to recognition of a priority in reorganization proceedings. The railroad reorganizations which followed the panic of 1893 severely tested the indentures of that day, and as a result of the extensive studies made at that time many details of the modern form were settled. ${ }^{18}$

During this gradual evolution the trustee's express powers, and to a lesser extent its duties, were constantly increased,"9 largely in the interests of the investor. The individual began to be supplanted by the corporate trustee, ${ }^{21}$ at first to avoid the problems incidental to a trustee's death, ${ }^{22}$ later to assure greater competence under the growing burden. Authentication and certification, the authorization of collateral release, the approval of the issue of additional indenture securities and many other duties, mostly of a ministerial character, were imposed upon the trustees for discharge before default, during the normal life of the trust. But there is no evidence that the business intention was at any time to give the trustee active supervision over the obligor's fulfillment of his obligations. ${ }^{23}$ The numerous covenants designed to prevent impairment

18. Stetson, sipra note 6 , at $8,16,21,22,24$. The statement in the REForT, p. 9, that "since security holders generally are not discriminating in appraising the adequacy" of indenture provisions, it generally adds nothing to the sales value of the sceurity to insert in it adequate protective clauses" may have limited specific application, but talien broadly it seems erroneous.

19. Stetson, supra note 6 , at 13 .

20. For a list of typical duties imposed by the modern indenture, see MfcCollom, The Securitics and Exchange Commission and Corporate Trustecs (1936) 36 CoL. L. REv. 1197, 1205 ff.

21. It has been stated that the earliest corporate indenture to a corporate trustce was made by the President and Directors of the Beaver Mreadow Railroad and Cosl Company to the Girard Life Insurance, Annuity and Trust Company in 1839. Corporate trustees became general after 1880. Smith, stipra note 6, at $908,911$.

22. See SEORT, op. cit. supra note $6, \S 258$. When John Davis, one of the trustees under the New York and Erie Railroad Company mortgage of 1853, died, a supplemental instrument was used to secure the substitution of John C. Bancroft Davis (later reporter of the United States Supreme Court) as successor trustee.

23. MfcCollom, supra note 20 at 1202 . The opposite is indieated, if not established, by the proliferation of exculpatory and immunity clauses. 
of the security were covenants of the obligor, and the trustee's duties were to receive and check statements of the obligor or its agents showing that the proper requirements were being uniformly observed. The additional responsibilities appear to have been confided to the trustee not as the aggressive champion of the security-holders, but as a person of competence and impartiality who would administer these duties with mechan* ical exactitude. ${ }^{24}$ With respect to the period before the occurrence of a serious default, the ideal of the corporate indenture trustee, as evolved by men of business for a business purpose, may be stated in terms of an impersonal mechanism, reacting automatically in the predetermined way whenever action should be necessary. After default the duties of the trustee might become onerous and exacting to a degree, but as usually a court soon stepped in to command the property and order reorganization most of these extraordinary responsibilities would normally be of short duration.

If this was the trustee's intended position, however, it was at times very difficult to obtain its judicial recognition. ${ }^{25}$ Eighty years ago a state supreme court, admitting the novelty of such trustees and secking to locate them accurately, respected the tradition of the name and conclucled that the indenture trustee, at least after foreclosure, was bound by the same standards of fiduciary obligation that a private trustee must observe towards his beneficiaries. ${ }^{26}$ The forthright language of this decision has

24. See Posner, supra note 6 , at 202. For a discussion of the trustee's position, as seen at the end of the nineteenth century, see SHORT, op. cit. supra note 6 , at $\$ \$ 258$, 270-271; Fowler, Legal Responsibility of Trustecs under Corporate Bonds and Mortgages, or Deeds of Trust (1890) 24 AM. L. Rev. 703.

25. See SHORT, op. cit. supra note 6 , at $\$ \S 270-271$; JoNEs, op. cit. supra note 6, at $\S \S 357,360$; Posner, supra note 13, at 739, 794.

26. Sturges v. Knapp, 31 Vt. 1 (1858). This case involved a bill in equity brought by holders of the majority of the indenture securities against the trustees, who had forcclosed after default and subsequently leased the mortgaged premises. The bill sought the appointment of a receiver and avoidance of the lease, on the grounds that the trustees, after foreclosure, were trustees of a "mere nominal, naked or dry trust" and had no powers or duties except to convey the estate to the cestuis. The bill was dismisscd, by a divided court. Chief Judge Redfield, for the majority, said in his opinion: "We thinl: it could scarcely escape the notice of any one, who had seriously and patiently attempted to master this question, that until the actual foreclosure of the mortgage the trusts involved in the contract and imposed upon the trustees named are entirely fiduciary and executory. At first, and so long as prompt payment is made, it is understood, in prac* tice indeed, that the office of such trustees is rather silent, and the duties of the trustess, by means of the negotiability of the bonds and of the coupons attached, are ordinarily performed, or expected to be performed, by the corporation or its officers . . .

"But after the forfeiture occurs either by non-payment of interest or principal, or both, as in the present case, the duties of the trustees become, not only active and responsible but critical and delicate. It not only is not a dead, dry trust, but is one of the most active and momentous responsibility ...." Pp. $54 \mathrm{ff}$.

The remainder of the opinion develops the extent and character of that responsibility. The comments of a dissenting judge upon this decision, in the later case of Miller $v$. Rutland and Washington R. R., 36 Vt. 452, 483-484 (1863), are of interest. 
had a strong influence. No courts have gone so far as to hold the trustee to such a standard before default, but there has been a willingness to "imply" duties before default from the nature of the relationship between trustee and security holders, even though such duties are not found in, or are expressively negatived by, the terms of the indenture itself. ${ }^{2 t}$ The distance which this theory of implication might be carried in any case remains conjectural, for the decisions have neither limited nor defined it to a trustworthy extent.

For nearly a century corporate trust indentures, no doubt with these holdings in mind or in prospect, have included exculpatory clauses relieving trustees from all liability except for gross negligence or wilful default. $^{28}$ These clauses were not indigenous to corporate indentures;

27. Miles v. Vivian, 79 Fed. 848 (C. C. A. 2d, 1897); Frishmuth v. Farmers Loan \& Trust Co., 95 Fed. 5 (C. C. S. D. N. Y. 1899), aff'd, 107 Fed. 169 (C. C. A. 2d, 1901); Guardian Trust Co. v. White Cliffs Portland Cement \& Chalk Co., 109 Fed. 523 (C. C. W. D. Ark. 1901); Old Colony Trust Co. v. City of Wichita, 123 Fed. 762 (C. C. D. Kans. 1903); Guaranty Trust Co. v. Atlantic Coast Electric R. R., 133 Fed. 517 (C. C. A. 3d, 1905); New York Trust Co. v. Michigan Traction Co., 193 Fed. 175 (W. D. Mich. 1912); Hoffman v. First Bond \& Mlortgage Co., 116 Conn. 320, 164 Atl. 656 (1933) ; Lyman v. Stevens, 123 Conn. 591, 197 Atl. 313 (1938); Mryers v. Ameriean National Bank \& Trust Co., 277 Ill. App. 378 (1934); First National Fire Insurance Co. v. Salisbury, 130 Mass. 303 (1881) ; Polhemus v. The Holland Trust Co., 59 X. J. Eq. 93, 45 Atl. 534 (1900), aff'd, 61 N. J. Eq. 654, 47 Atl. 417 (1900); Rhinelander v. Farmers Loan \& Trust Co., 172 N. Y. 519, 65 N. E. 499 (1902); Patterson v. Guardian Trust Co., 144 App. Div. 863, 129 N. Y. Supp. 807 (3d Dep't 1911); Starr v. Chase National Bank, N. Y. L. J. Sept. 21, 1936, p. 771, col. 6 (Sup. Ct.) ; Nay Aug Lumber Co. v. Scranton Trust Co., 240 Pa. 500, 87 Atl. 843 (1913); Moyer v. Norristown-Penn Trust Co., $296 \mathrm{~Pa}$ 26, 145 Atl. 6\$2 (1929); Welch v. Northern Bank \& Trust Co., 100 Wash. 349, 170 Pac. 1029 (1918); Stuhr v. Yakima Valley Bank \& Trust Co., 149 Wash. 400, 271 Pac. 82 (1928); Marshall \& Ilsley Bank v. Guaranty Investment Co., 213 Wis. 415, 250 N. W. 862 (1934). See also Mercantile Trust Co. v. Portland \& Ogdensburg R. R., 10 Fed. 604 (C. C. D. N. H. 1882); Continental Savings Banls v. New Orleans Drainage Co., 278 Fed. 811 (E. D. La. 1922); Merrill v. Farmers Loan \& Trust Co., 24 Hun 297 (1st Dep't N. Y. Sup. Ct. 18S1) ; 2 Perry, Trusts A:id Trusters (7th ed. 1929) \$749; Bangs, The Powcrs and Duties of a Trust Company When Acting As Trustee Under a Corporate Mortgage (1898) 15 Baxk. L. J. 79; Fowler, supra note 24; (1931) 40 Yale L. J. 1110; (1934) 47 Hakv. L. Rev. 882; (1934) 18 Ilrai. L. REV. 604.

28. The earliest example of such a clause which the author has found is in an indenture of Lehigh Coal and Navigation Company to Josiah Wh'hite (the "principal agent" of the company), Caleb Cope and James Cox, trustees, dated Alarch 7, 1842. The provision, found at pages 7-8 of the printed document, states that the trustees and their successors, heirs, etc., "shall at all times hereafter be indemnified by and out of the said mortgaged premises for all their lawful actings and doings therein in preference to any other person or persons, and shall not be responsible any one for any other of them, or for the actings or acts or doings of the said managers, or of any person or persons by the said parties to these presents or any or either of them nominated, appointed or cmployed as aforesaid in the concerns thereof, or for any error of judgment, but only each for his own individual act of wilful wrong." This indenture, which secured $\$ 6,150,000$ of outstanding loans and bonds to be issued, also contained an acceleration clause. 
similar provisions of various sorts in wills and inter vivos trusts had been considered intermittently by the English courts for at least half a century, and on several occasions they had been held to be futile. ${ }^{29}$ The corporate indenture, however, developed them in various ways and provided other means as well for escaping immediate responsibility. A clause was devised relieving a trustee from any duty to act unless indemnified, ${ }^{30}$ and the request of a single security holder as a prerequisite to action ${ }^{31}$ was changed to a request from the holders of a certain percentage of the indenture securities. Similarly, notification by a proportion of the security holders became a condition precedent to holding the trustee responsible for lnowledge that a default existed. ${ }^{32}$ As the trustee's duties increased specific exculpatory clauses appeared and multiplied, until in a modern indenture they may seem to shield a trustee from almost every mistake and misfortune. ${ }^{33}$ But the actual effect of these sheltering devices is problematical, for the American courts no less than the courts of England regard them with evident distaste. In a number of instances their effect has been avoided on one pretext or another, and in some cases they have been directly overridden in decisions. ${ }^{34}$ Because they undoubtedly perform some service

29. Sadler v. Hobbs, 2 Bro. C. C. 95, 29 Eng. Rep. 66 (1786) ; Brice v. Stokes, 11 Ves. 319, 32 Eng. Rep. 1111 (1805) ; Mucklow v. Fuller, Jac. 198, 37 Eng. Rep. 824 (1821) ; Moyle v. Moyle, 2 Russ. \& M. 710, 39 Eng. Rep. 565 (1831) ; Pride v. Fools, 2 Beav. 430, 48 Eng. Rep. 1248 ( 1840) ; Fenwick v. Greenwell, 10 Beav. 412, 50 Eng. Rep. 640 (1847) ; Drosier v. Brereton, 15 Beav. 221, 51 Eng. Rep. 521 (1851); Dix v. Burford, 19 Beav. 409, 52 Eng. Rep. 408 (1854) ; Brumridge v. Brumridge, 27 Beav. 5, 54 Eng. Rep. 2 (1858) ; Budge v. Gummow, L. R. 7 Ch. App. 719 (1872); Cassels, The Effect of Indemnity Clauses upon Trustes' Liability for Wilful Default and Neglect, (1889) 9 CAN. L. T. 1; Shinn, Exoneration Clauses in Trust Instruments (1033) 42 Yate L. J. 359.

The report of Pride v. Fooks, supra, says (pp. 432, 1249): "The will containct the usual trustee clauses, that he should only be accountable for losses happening through his wilful neglect and misconduct, and that he might reimburse himself all costs, charges and expences," and there is a similar reference to the "usual clauses" in Moyle v. Moyle, supra, at pp. 710, 566. See also the headnote to Mucklow v. Fuller, supra.

30. See the New York and Erie Railroad mortgage of August 15, 1857, providing "That neither Trustee shall be answerable for the acts, omissions or defatilts of the other" to which he does not give his assent: That each shall be answerable for gross negligence and wilful defaults only .. . That the Trustees shall not be required to act in the execution of these trusts, except at their own option, unless the party requesting them so to do shall furnish them reasonable indemnity against the loss, cost, trouble and expense, they may be at in so doing."

31. Such request was requisite for action to foreclose under the Erie mortgage of March 1, 1849.

32. This is the so-called "ostrich clause," which is of doubtful effect. See infra note 34.

33. For a discussion of the superior effectiveness of these specific clatses, as contrasted with the general immunity clause, see Posner, supra note 13, at 788.

34. These cases have widely divergent grounds of decision. Frishmuth v. Farmers Loan \& Trust Co., 95 Fed. 5 (C. C. S. D. N. Y. 1899), aff'd, 107 Fed. 169 (C. C. A. $2 d, 1901$ ) (liability predicated upon implied duties, immunity clauses being disregarded); 
in mitigating liability, they remain in all their absurd redundancy. If they were removed from indentures of the present day, synthetic theories of liability devised to overcome them, and real liabilities which they have partially stemmed, might combine to overwheln the trustee. But they do not afford the complete escape from responsibility which they seem to offer, and, except in their variety and the extent of their repetition, they do not represent a modern development.

If there is any assurance to be derived from an historical survey of the corporate trust indenture, it is that none of the present-day problems are new. There has been, obviously, a great change in the physical character of the security, and that has affected the nature and value of the security holder's remedies. There has also been a change in the trustees,

Richardson v. Union Mortgage Co., 210 Iowa 346, 22S NY. WV. 103 (1930) (wilful default found, and also held that the trustee transcended its powers); MIullen v. Eastern Trust \& Banking Co., 108 Mie. 498, 81 Atl. 948 (1911) (exculpatory clause construed to be inapplicable); Deposit Bank \& Trust Co. v. St. Paul Trust Co., 185 MLinn. 25, 239 N. W. 766 (1931) (exculpatory clause ineffective when trustee apparently failed to apply funds properly); Conover v. Guarantee Trust Co., 88 N. I. Eq. 450, 102 Atl. $\$ 44$ (1917), off'd, 89 N. J. Eq. 584, 105 Atl. 890 (1917) (trustee transcended its powers); Rhinelander $v$. Farmers Loan \& Trust Co., 172 N. Y. 519, 65 N. E. 499 (1902) (implied duties not affected by exculpatory clauses); Hunsberger v. Guaranty Trust Co., 164 App. Div. 740, 150 N. Y. Supp. 190 (1st Dep't 1914), aff'd, 218 N. Y. 742, 113 N. E. 1058 (1916) (question of gross negligence should have been given to jury); Doyle v. Chatham \& Phoenix National Bank, 253 N. Y. 369, 171 N. E. 574 (1930) (trustee transcended its powers, liable for misrepresentation), Comment (1930) 40 YALE L. J. 138, (1931) 31 CoL. L. Rev. 858, (1931) 15 Mins. L. Rev. 477; Harvey v. Guaranty Trust Co., 134 Misc. 417, 236 N. Y. Supp. 37 (Sup. Ct. 1929), aff'd scithout opinion, 239 App. Div. 774, 242 N. Y. Supp. 905 (1st Dep't 1930), aff'd for curiam, 250 N. Y. 526, 177 N. E. 125 (1931) (immunity clause no protection for unauthorized acts "repugnant" to the trust); Starr v. Chase National Bank, N. Y. L. J. Sept. 21, 1936, p. 771, col. 6 (Sup. Ct.) (wilful default found, but also held that the "ostrich clause" and other immunity" provisions do not protect a trustee from liability for defaults "repugnant" to the trust); Colonial Trust Company's Appeal, $241 \mathrm{~Pa}$. 557, 88 Atl. 798 (1913) (wrongful payment not excusable as a mistake of judgment); Welch v. Northern Bank \& Trust Co., 100 Wash. 349, $170 \mathrm{Pac}$. 1029 (1918) (trustee liable upon implied obligations, an immunity provision being disregarded); State v. Comer, 176 Wash. 257, 28 P. (2d) 1027 (1934) (exculpatory clause ineffective because in conflict with the rest of the instrument); Marshall \& Ilsley Bank v. Guaranty Investment Co., 213 Wis. 415, 250 X. W. 862 (1934) (implied duties imposed regardless of exculpatory provisions, including the "ostrich clause"); Whicher v. National Trust Co., 22 ONT. L. Rex. 460 (1910) (trustee aeted beyond its powers), rec'd. National Trust Co. v. Whicher, [1912] A. C. 377. See also Holmes v. McDonald, 226 I11. 169, S0 N. E. 714 (1907) (trustee of voluntary association); Digney v. Blanchard, 226 MFass. 335, 115 N. E. 424 (1917) (trustee of Massachusetts trust); Tuttle v. Gilmore, 36 N. J. Eq. 617 (18S3) (trustee of personal trust); Fay v. New York Trust Co., N. Y. L. J. Oct. 30, 1936, 0. 455, col. 7 (casting doubt on the validity of the "ostrich clause") ; PAGE AND GATEs, op. cit. supro note 6, at 152-154; Jones, The Corporate Trusice Problcm (1937) 26 KY. L. J. 3, 32-38; Payne, Exculpatory Clatuses in Corporate Mortgages and Other Instruments (1934) 19 Coa:. L. Q. 171; Posner, stipra note 13, at 780-790; Comments (1931) 29 AIICr. L. Rev. 355, (1933) 33 CoL. L. Rev. 97, (1937) 37 CoL. L. Rev. 130, (1937) \& U. of Crr. L. Rev. 346. 
which are now more competent, often more disinterested, and generally more vulnerable to lawsuits because of the extent of their activities. The institutional investor, with adequate research facilities and considerable powers of self-protection, has grown to be a factor of importance. Defaults of an obligor are probably less easy to conceal, because of widespread private and governmental publicity, than at any previous time. Indenture financing still works with unusual success. ${ }^{35}$ Why, then, has the corporate trust indenture at this juncture been made the subject of investigation and bitter criticism, and what is the reason for the assertion that now the public interest requires a revolutionary change?

The answer may be found in many factors. The depression commencing in the United States in 1929 brought numerous defaults in indenture securities, and they in turn exposed in the most unfortunate manner excesses characteristic of the preceding years. The financial community and many trustee institutions suffered a precipitate decline in public esteem. Further, the typical modern indenture instrument had grown to ridiculous proportions ${ }^{36}$ and its extravagantly complicated phraseology exemplified the worst obscurantism of the law ${ }^{37}$ its form had no defenders. The use of the term "trustee" in a unique and undefined sense ${ }^{38}$

35. The new domestic corporate issues of long-term bonds and notes, undoubtcdly for the most part indenture securities, for each of the last ten years for which figures are available, are as follows:
1928; new capital, $\$ 2,174,844,000$; refunding, $\$ 999,300,000$.
1929 ; new capital, 1,873,464,000; refunding, 495,900,000.
1930 ; new capital, 2,459,676,000; refunding, $350,652,000$.
1931; new capital, 950,664,000; refunding, 677,304,000.
1932; new capital, 271,044,000; refunding, 134,796,000.
1933; new capital, 23,616,000; refunding, $114,876,000$.
1934; new capital, 112,104,000; refunding, 174,936,000.
1935; new capital, 322,944,000; refunding, $1,743,120,000$.
1936; new capital, $816,456,000$; refunding, $3,146,820,000$.
1937; new capital, 743,520,000; refunding, $801,588,000$.
Total new capital, $\$ 9,748,332,000$. Total refunding, $\$ 8,639,292,000$.

U. S. Dept. of Comarerce Survey of Current Business (Supp. 1938) 70-71. The tatals of similar issues of short-term bonds and notes for the same period are: new capital, $\$ 1,385,868,000$, refunding, $\$ 823,956,000$, and these include an indeterminate proportion of indenture securities as well. Ibid.

36. It is commonly referred to as "the largest of all legal documents." Draper, supra note 6 , at 94 . Its complexity is best appreciated by reference to one of the elaborate charts or guides published to assist practising lawyers, c.g., Eston, ExpLANATOIY DUT* LINE OF THE Functions and ReQuirenents of BANkers, Trustees, Registhats, Transfer Agents and Lawyers in Connection with the Issue of INvestment St:curities (1928); Harding, Corporate Securities: A Chart for Use in Detrerinining Their Validity (1917).

37. An illuminating and entertaining view of the situation is given in Drinker, Concerning Modern Corporate Mortgages (1926) 74 U. of PA. L. REv. 360.

38. There also may be some question whether the term was not exploited to sell indenture securities. It has long been recognized that a responsible trustee adds to the 
jarred at a time when the public was being constantly shocked by revelations of abuse of fiduciary authority. A collapse of a real estate bubble, in which the indenture method had been obviously misused, ${ }^{30}$ cast discredit upon established types of indenture financing. As a result of all this there came a sudden and tremendous volume of litigation concerning the indenture and the functioning of the indenture trustee, ${ }^{40}$ and these lawsuits served to emphasize the confusion and insufficiency of legal precedents. Finally, it has been a period distinguished both by ambitious reforms and a political program of extending controls; and the popular enthusiasm for reform has at times itself compelled, and has more often been invoked to justify, a transfer of power from the business and financial world to a place more nearly within the political orbit.

Each of these original influences is still strong, although events and the passage of time have tended to emphasize the political aspects while limiting the importance of others which were formerly prominent. All have had effect upon the present form of the Barkley Bill, and that effect must be considered. But the evaluation of the measure itself should not be adjusted to contemporary currents; it should, so far as possible, be kept apart from the storm and controversy of both the present and the all too recent past.

\section{The Securities and Exchange Comanission's Report}

The Commission's Report upon corporate indenture trustees has received extensive comment in legal periodicals, ${ }^{41}$ and no attempt will be made now at a detailed review. A general consideration of it, however, is necessary to an understanding of the Barkley Bill, which embodies its recommendations and carries out its theory.

The Report is a forceful presentation of case histories which illustrate defects in indentures and shortcomings of trustees, with some instances of active fraud. It is dramatically written, and throughout it shows a great deal of skilful research at the service of strong conviction. It casts a vivid light upon many particulars of the present practice which are in need of illumination. It has, however, a thesis, forecast in the introduction and continuously evident to the end: that corporate indenture trustees, in the interests of the investing public, must be stripped of all

saleability of bonds [Knapp v. Railroad Co., 20 Wall. 117, 123 (U. S. 1873)], but this does not, of course, necessarily imply misrepresentation or general misunderstanding of an indenture trustee's limited functions.

39. See Part III of the Reports of the Securities and Exchange Commission, Committees for the Holders of Rcal Estatc Bonds (1936); JicCollom, supra note 20, at 1218.

40. See Posner, sttpra note 13, at 739.

41. It is vigorously criticized in $\mathrm{AICCollom}$, supra note 20, and Wham, Trustecs Under Indentures (1937) 23 A. B. A. J. 179. See also Posner, supra note 13; Comment, Protection for Debenture Holders (1936) 46 YALE L. J. 97 ; Jones, supra note 34; Rodwin, Trustees under Indentures-The Old Order Changes (1937) 3 Conp. Reong. 223. 
conflicting interests and changed into active trustees with full fiduciary duties. Although this thesis is a conclusion drawn from extensive evidence, it appears to have determined the selection of the material incorporated in the Report, for little if anything is included which does not advance the argument. ${ }^{42}$ In consequence the Report requires considerable supplementation which will, in a number of instances, tend to modify its conclusions.

First in importance among the additions needed, an essential if the Report is to be treated as a basis for proposed legislation, is an adequate measurement of the cases it describes against the present law of corporate indentures. ${ }^{43}$ The insufficiency of the specific references made to the law in the Report permits some incorrect inferences. The treatment of exculpatory clauses is a prominent example, for there is little in the Report to suggest that the protection they offer a trustee is often equivocal, although that fact is of undoubted significance and goes far to explain why the best trustees already observe many of the standards which the Commission would make obligatory. ${ }^{44}$ Shortly before the publication of the Report, Hazzard v. Chase National Bank ${ }^{45}$ was decided. In that case, an exculpatory clause was effective to shield a negligent trustee. The decision, and particularly its long and sharply worded dictum attacking present indenture practice and calling for legislation, ${ }^{40}$ is relied upon heavily, but one may reasonably doubt whether the trustee would have been equally fortunate in another jurisdiction or in slightly altered circumstances. Beyond any question some of the trustees whose activities the Report describes would be held liable to security holders by any court, despite exculpatory clauses, if in litigation the descriptions could be established as accurate. ${ }^{47}$

42. Other parts of the Commission's reports on Reorganization and Protective Committees have this characteristic. See Dodd, The Securitics and Exchange Commission's Reform Program for Bankruptcy Reorganizations (1938) 3S CoL. L. Rtv. 223, 225; Swaine, "Denocratization" of Corporate Reorganizations (1938) 38 CoL. L. Rtw. 256. 258.

43. Mr. Posner's scholarly and valuable article, supra note 13 , supplies just stuch a background.

44. See MICollom, supra note 20, at 1220 . See also note 80 infra. The Reronr concedes that some of its criticisms are inapplicable to the highest type of corporate trustce. REPORT 25, 31.

45. 159 Misc. 57, 287 N. Y. Supp. 541 (Sup. Ct. 1936).

46. 159 Misc. 57, 83-85, 287 N. Y. Supp. 541, 569-572 (Sup. Ct. 1936). Justico Rosenman speaks of "how utterly unjust to the investing public is the modern trist indenture ... It is becoming increasingly clear that these indentures, though legally permissible, have all the potentialities of fraud upon innocent investors . . . This indenture was particularly vicious . . . For the inexcusable terms of the indenture, the trustee cannot be held accountable."

47. For example, various trustees are described in the REPORT as "flagrantly derelict in the performance of their duty" (p. 18), accepting certificates improper on their face (pp. 27-28, 35), deliberately suppressing news of a default in order to control a reorgani- 
Further information than the Report gives is also needed on the nature of the trustee's duties and the manner in which, broadly throughout the corporate indenture field, they are performed. It is implied at least once in the Report that, in theory, indenture trustees at one time were the acknowledged equivalents in responsibility of personal trustees, ${ }^{43}$ and that their present restricted activity is a departure dictated by self-interest. An assumption of this character, which does not accord with the history of these indentures, may be responsible for inferences and statements, scattered through the Report, that the modern trustee's relative passivity is disreputable if not immoral. ${ }^{49}$ Both the duties actually performed by the modern trustee and the risk it assumes are considerably understated in the Report, ${ }^{50}$ and there is little attention paid to the fact that the best trustees at the present time generally comply with a high standard of fiduciary conduct. ${ }^{51}$

A question of salient importance in balancing the advantages and risks of legislation, and one to which the Report offers no answer, is the actual extent of the loss suffered by investors by reason of specific faults of the present practice, particularly the inactivity of trustees. This is undoubtedly very difficult to estimate, although in particular instances the damage is susceptible of calculation. ${ }^{2}$ A few cases of obvious maladministration and consequent loss are leads, but they cannot be taken as representative in the absence of additional evidence. ${ }^{53}$ Obviously the usual

zation (p. 42) and guilty of "flagrant abuse of fiduciary duty" (p. \$7). These instances would all appear to fall within "gross negligence or wilful default," for which a corporate trustee would invariably be liable notwithstanding immunity provisions. A clause assuming to protect against such transgressions would be void as against public policy. See Browning v. Fidelity Trust Co., 250 Fed. 321,325 (C. C. A. 3d, 1918). The emphasis of these cases shifts to the practical point that abuses exist for which liability, although legally certain, is not always a deterrent because security holders, lacking the inquisitorial powers of an investigator with Congressional authority, are unable to obtain the facts.

48. "The remedy is to require a return to the theory that a corporate trustee is a trustee, and that it cannot pretend to be such unless it meets the qualifications, assumes the duties and discharges the responsibilities of a trustee." REPOnT 69.

49. E.g., [An instance of diverting income] "is symptomatic of the disrepute into which trusteeship under indentures has fallen." P. 82. "The indictment of the whole system of corporate trusteeships implicit in [a witness'] testimony is no overstatement." $P$. 98. "Such measures [as those the REPORT recommends] would go far towards curbing the exploitation of investors which has occurred either at the hands of the trustce itself or at the hands of the reorganization and management groups with the knowledge, consent, or acquiescence of a complacent and inactive trustee." P. 112.

50 Compare Report 68, 70 with MrcCollom, supra note 20, at 1205 ff., 1222.

51. Posner, supra note 6, at 248; see note 80, infra.

52. E.g., in cases of substitution of collateral or violation of negative pledge clauses. See REPORT 10-22. In other instances cited the responsibility for the loss is difficult to locate. See Report 94.

53. The statement at page 37 of the REPORT that "there is ample evidence that [a trustee's acceptance of obviously improper statements, inter alia] refiect the attitude and 
instance of fraud or hidden default occurs when the issuing company is already in difficulties and the security impaired. An obligor will ordinarily attempt to comply with its obligations as long as it can. The Report does not justify contradiction of a statement, made in defense of modern corporate trustees, that the number of cases where loss may be fixed upon a failure of the trustee to act, as distinguished from mismanagement, bad business conditions, or one of the indenture faults generally admitted, are relatively few. ${ }^{54}$ How much damage really results from defective indentures is likewise uncertain.

A further study of the investment banker's role as a representative of the investors would be welcome. In the cases upon which the Commission obtained data, the investment banker participated in drafting the indenture a good part of the time, ${ }^{55}$ and it would seem clear that in the 1tstial instance he must at least have passed upon the fitness of the instrument before engaging to underwrite the securities. It is true that his primary concern would be with matters other than the prospect of defatlt, but there is good reason to believe that his interest in the indenture's protection of prospective purchasers is not as perfunctory as the Report implies. ${ }^{56}$ When disaster overtakes a certain security the investment banking house which marketed it inevitably suffers. Probably it makes little difference to the individual investor whether the loss is attributable to a faulty indenture or to broader causes; but the blame for inclenture defects would be particularly easy to fasten on the distributor. It wotld be illuminating, in connection with the case histories of securities issted under unfair or deceptive indentures, to follow the fortunes of the banking houses which sold them. ${ }^{57}$

practice of corporate trustees generally" requires further support. It is possible that the transcripts of testimony taken before the Commission, to which this author has not had access, contain additional instances, but the REPORT makes no reference at this point, although in many other parts the REPORT is fully annotated to the transcripts.

54. McCollom, supra note 20 at 1216-1218, 1226-1227.

55. REPORT 7, 124.

56. REPORT 9-10. See Stetson, supra note 6, at 8, 21, 22; McCollom, supra note 20, at 1213-1214; Douglas and Bates, The Federal Secutritics Act of 1933 (1933) 43 Yatr: L. J. 171, 199-200.

57. The Kreuger \& Toll debentures are given as an instance where huge loss resulted from an unsound substitution clause. The subsequent collapse of the firm of Lec, Higginson \& Co., which marketed these securities, is familiar history. In another instanco the REPORT states [pp. 54-55] that the investment banking houses made a substantial settlement with representatives of bondholders under the threat of suit on $a$ basis of fraud. For the history of American Bond \& Mortgage Co. and the various Stratus com* panies, frequently cited by the REPORT in connection with frauds and defaults in rcal estate mortgages, see Part III of the Commission's Reports, supra note 39; In re Amer* ican Bond \& Mortgage Company, 61 F. (2d) 875 (C. C. A. 7th, 1932); In re S. W. Straus \& Co., 67 F. (2d) 605 (C. C. A. 2d, 1933). A significant relation is indicatcd, although any direct connection between defects in an indenture and failure of an invest- 
A related subject which the Report neglects is the effect of the Securities Act of $1933^{58}$ and the Securities Exchange Act of 1934. ${ }^{59}$ The provisions of the Securities Act which require full disclosure in a prospectus will undoubtedly operate to correct some flaws in indentures; for a prospectus setting forth accurately, as it now must, ${ }^{\text {cin }}$ a faulty substitution clause, or a negative pledge clause which leaves an easy avenue for evasion, would be detrimental to the security's anticipated market. Indentures which are to be subject to the Securities Act can no longer have their defects concealed, ${ }^{61}$ and in consequence draftsmen will be strongly influenced to take pains to have as many defects as possible eliminated. The Report does refer ${ }^{62}$ to the powers given the Commission by the Securities Exchange Act to alter and supplement security listing requirements on the national exchanges, but their usefulness is minimized, ${ }^{63}$ and the possibilities of the two Acts are not explored. ${ }^{64}$

The Report contains a good amount of material dealing with the specialized field of real estate bonds, where abuses have been patent. As these cases are not at all representative of corporate indentures generally, ${ }^{65}$

ment banking house may be impossible to establish. It should be observed, however, that a cause of action against a corporate trustee might often be of greater value to a security holder than a similar cause of action against an investment bantier.

58. 48 Star. 74 (1933), as amended by 48 St.1т. 881 (1934) and 49 Srat. 557 (1935), 15 U. S. C. c. $2 A$ (Supp. 1937).

59. 48 StAT. 881,15 U. S. C. c. 2B (1934).

60. Securities Act, §12. See McCollom, supra note 20, at 1215.

61. Two instances cited to support the conclusions of the Reront involved a prospectus that was incomplete or misleading: Hazzard v. Chase National Banl, 159 Mfise. 57, 287 N. Y. Supp. 541 (Sup. Ct. 1936), and the Union Power Corporation banlaruptey; pp. 18, 20, 55-57.

62. At p. 110.

63. The REPORT points out that these listing requirements "reach only the rather limited classes of securities dealt in on such exchanges," and that they cannot be made too exacting without risk that issuers will prefer to keep their securities off the exchanges in order to be free to choose their own forms of indentures and trustees. Id. at 110.

64. One excellent suggestion is, however, included in the REPont, although not reflected in the Barkley Bill. At page 31, with reference to assuring that proceeds of indenture securities will be applied in accordance with the indenture's terms, the RErors states: "The trustee's hand might be strengthened in this conneetion by requiring the filing of certificates of proper application of proceeds as supplements to registration under the Securities Act of 1933, as amended, and the Securities Exchange Act of 1934. Potential liability thus created for misstatements in these certificates would tend to discourage improper application of proceeds."

Another respect in which the Barkley Bill is not in accord with the RErom is the matter of the trustee's powers. The REPORT concedes that the modern indenture generally gives a trustee sufficient powers and need not in that respect be amplified. Id., at 42,61 . But compare $\$ 302(a)(2)$ of the Bill.

65. See the justified criticism of $\mathrm{Mic}$ Collom, supra note 20 , at 1216, 1218-1219, 1227, which points out that the important institutional trustees have very few real estate indentures. 
they should be segregated ${ }^{66}$ and not used as a basis for conclusions affecting the whole of modern indenture practice.

All these factors deserve further consideration than the Report accords before the nature and advantages of additional legislation can be properly weighed. Finally, attention should be forcefully directed to the Report's dominant characteristic: it is concerned solely with the investor's interests. It contains no mention of the interest of the issuer, which is fundamental. It pays scant attention to the desirability of maintaining a free flow of capital and the remarkable effectiveness of indentures as a means of sound and proper financing. These are, of course, primiry consideram tions, entitled to greatest weight in judging the merits of remedial legislation. Their neglect in the Report emphasizes that it is rather a brief in a special cause than an adequate survey of the present situation.

These comments upon the Report are not tendered, however, in a hostile spirit. They stress the negative aspect because in its positive contributions the Report speaks eloquently for itself. A powerful brief can energize immediate corrective activity, where a more judicious document might fail, and in this the Report, even taken without the Barkley Bill, has been a signal success. ${ }^{67}$ It proves conclusively that trustees have been often lax at times of serious defaults when action to protect security holders was imperative. Conflicts of interest, to a degree undoubtedly damaging and close to the border of fraud, are strikingly revealed, and one may be certain that far more cases than appear in its pages are matter of common knowledge in financial centers. Weakness in indenture provisions, particularly negative pledge clauses and provisions for the release and substitution of security, is fully demonstrated. Although some of the subjects the Report touches are controversial, in these important matters improvement is clearly to be desired, and the only question is the best method by which it may be obtained. The conclusion of the Report is that the provisions of trust indentures should be controlled by federal law, which should also prescribe qualifications for trustees, require them to be active, and hold them to a high fiduciary standard. The Barliley Bill is the full and logical expression of this theory.

\section{The Barkley BiLl}

In the form in which it has now been introduced in the Seventy-Sixth Congress, ${ }^{68}$ the Barkley Bill represents the original measure, prepared

66. New York has dealt with them separately in the "Streit Law." N. Y. Rt'AL Prop. LAw, $\$ \$ 124-129,130$ (a)-(j), added by Laws, 1936, c. 900.

67. See Kuhn, The Securities Act and Its Effect Upon the Institutional Intistor (1937) 4 Law and Contens. Prop. 80, 82.

68. This article deals with the present House bill, H. R.2191, 76th Cong., 1st Sess., except where specific reference to earlier drafts is made. Copies of the present Senate bill, S. 477, are not available at the time of writing, but it is understood to be identical 
largely by the Securities and Exchange Commission, modified ${ }^{63}$ as a result of the committee hearings in both the Senate and the House and through frequent informal conferences in which representatives of insurance companies, investment bankers, mutual savings banks, commercial banks and institutional trustees have participated. ${ }^{70}$ The present form has received qualified approval or pledges of non-opposition from representatives of each of these groups ${ }^{71}$ with the apparent exception of the investment bankers, who have expressed strong opposition. ${ }^{72}$ There is no record, at least in the published transcripts of the committee hearings, that issuers, either individually or through associations, have made their opinion known in any way.

with the measure introduced in the House. The Barkley Bill passed through four committee prints in the Senate of the 75th Congress. A hearing was held, after Committee Print No. 2 was issued, on June 9,15, 22 and 29, 1937, before the Securities and Exchange subcommittee of the Senate Committe on Banking and Currency. Hearings Before the Securitics and Exchange Subcommillec of the Commiltce on Banking and Currency of the Scnate, on S. 234t. 75th Cong. 1st Sess. (1937). The bill was reported favorably to the Senate April 19, 1938 [Report No. 161\%, Calendar No. 1695, 75th Cong. 3d Sess.] and was simultaneously introduced in the House. A hearing before a subcommittee of the House Committee on Interstate and Foreign Commerce was held April 25, 1938. Hearings Before a Subcommillec of the Commiltec on Interstalc and Foreign Commerce, House of Represculatizes, en II. R. 102/2. 75th Cong. 3d Sess. (1938). Records of these hearings will be hereinafter reierred to as SE:atre Hearnic and House Hearing, and Report No. 1619 in the Senate as Sexate Rerort.

69. The most important of the changes made in the Senate committec, 75th Congress, was the elimination of provisions barring debenture and certain other trustees from being at any time short-term creditors of the issuing companies. See Committee Print No. 2, $\$ 7(b)(6)$, reprinted in Senate Hearing 7. H. R. 2191 of the 76th Congress differs from the final form of the bills introduced in the preceding Congress mainly in matters of detail, the more important substantive changes being described infro in notes 102, 116, 123(10) and 128. H. R. 2191 presents the measure as an amendment to the Securitics Act of 1933, to be Title III of that Act (as the Lea Bill, H. R. 6968, 75th Cong., 1st Sess. (1937) was planned to be), and its sections are numbered 301-325. The changes in substance from the final form of the bills of the Seventy-Fifth Congress are to be found in $\$ \S 306(d) ; 308(b)(4),(5)$ and (9); 308(c); $310(b) ; 312(a),(e)(1)$ and (2); $315(\mathrm{~b})$; and 316 .

70. Senate Hearing 17, 87, 88, 89 ; House Hearixg 17, 58.

71. House Hearing 17-18, 43-47, 5S-61; Sendte Hesmixg 149. See also "Aims, Purposes and Philosophy of the Barkley Bill," an address by Edmund Burke, Jr., Assistant Director of the Reorganization Division, Securities and Exchange Commission, delivered at the annual meeting of the American Bar Association, Cleveland, Ohio, July 26,1938 . Whether any of the assenting organizations was in a position to engage in vigorous dispute with the bill's supporters at the time may be open to some question. When first introduced in the Senate the bill was critically received by the Bar. Report of the Committee on Administration of the Bankruptcy Law, Chicago Bar Association, January 14, 1938; Report of the Committee on Federal Legislation, Association of the Bar of the City of New York, March 1, 1938; see Posner, The Proposad Fcdcral MIcasure to Regulate Trust Indentures (1937) 71 U. S. L. Rev. 394. Comments of individual lawyers on later drafts will be found in Sex.ate He.1nixg 94-105, 108-122, 156-162; House HeARING 76-80.

72. House Hearing 72-75, 81-91. 
The bill provides for direct control of the terms of the indenture. Through that control it seeks to assure responsible trustees, free from conflicts of interest and urged to constant vigilance by imminent liabilities. The bill extends in general to every indenture under which the ordinary forms of securities shall be publicly issued in the future, ${ }^{73}$ both new indentures and existing indentures, ${ }^{74}$ except those already subject to some governmental regulation, ${ }^{75}$ and compliance is enforced by barring the use of the mails or any facility of interstate transportation for the sale or delivery of any security issued under an indenture which is not approved. ${ }^{76}$ The requirement of prior approval, or "qualification", of an indenture is comparable to registration under the Securities Act of 1933, and the two measures are also dovetailed in various ways, ${ }^{77}$ but their mutual resemblances are superficial. Procedurally they differ in that no "stop orders" are possible under the Barkley Bill, and once an indenture is "qualified" by receiving the Commission's approval the jurisdiction of the Commission ends except for the matter of requiring reports. $^{78}$ In substance the two differ fundamentally, for while the Securities Act requires only a full public disclosure of the contract and circumstances under which the securities are to be issued, the Barkley Bill takes charge of the contract itself and prescribes what its terms may and may not be. It is this new extension of theory which gives the Barkley Bill its particular importance.

A preliminary section of several paragraphs introduces the bill. This refers to the Commission's Report, sets out and describes as "widespread"

73. The bill applies to notes, bonds, debentures or evidences of indebtedness, and also certificates of interest or participation in, temporary certificates for, or guarantecs of any of these types. $\$ 304$ (a) (1). The bill does not apply to sales consummated within six months of its enactment $[\$ 304(a)(3)]$, and the Commission may in its discretion exempt indentures under which securities not exceeding $\$ 250,000$ in total are to be issued. $\S 304(\mathrm{c})$.

74. Further issues under already existing indentures shall, in case of proved hardship, be wholly or in some respects exempted by the Commission. $\$ 304$ (d).

75. The exemptions in the Securities Act of 1933 of governments, municipals, banl: securities, certain railroad securities, securities of charitable institutions, insurance policies, etc., are repeated in the Barkley Bill, except for securities issued in exchange for others of the same issuer, and securities issued under a plan approved by a court. $\$ 304$ (a) (4); Senate Report 9-10.

76. Section $305(\mathrm{a})$. Under $\$ 305$ (b) no Securities Act registration statement will become effective as to securities issued under an indenture which violates the bill's provisions.

77. E.g., each provides a twenty-day period for the Commission's examination, with automatic approval at the expiration of that time if no adverse action is taken. Barkley Bill, $\$ 306$ (c) ; Securities Act of 1933, as amended, $\$ 8(a)$. Filing fees under the Barkley Bill are to be deductible from the fees payable under the Securities Act. $\$ 306(b)$ of the Bill.

78. This is an exception which may have considerable importance. See note 123, infra, subsection (8). 
the various causes of trouble which the Report discusses, and concludes with a statement that the policy of the measure, which shall govern its interpretation, is "to meet the problems and eliminate the abuses" listed." Passing the question whether or not this introductory section overstates the case against the present-day indenture, ${ }^{80}$ it deserves attention because here, if anywhere, are limits imposed upon the Commission's right to exercise discretionary power, a subject which later will be discussed in detail.

Apart from the sections containing definitions, penalties, and various matters of procedure, none of which requires especial comment, the body of the Barkley Bill enumerates a great number of points of control in an indenture, which may be grouped into those where the control provided is specific and mandatory and those where it is indefinite or left to the Commission's discretion. As different considerations apply to each group, they will be taken separately, the specific provisions first. The most important of these establish qualifications for indenture trustees and provide for the elimination of exculpatory clauses.

\section{Trustees: Qualifications and Conflicts of Interest}

There is a dexterous approach to the troublesome problems of irresponsible trustees and trustees with conflicting interests. Instead of asking direct governmental supervision over trustee activities, as has been occasionally suggested, ${ }^{81}$ the Barkley Bill requires the indenture itself to set out in terms what the trustee must be and what relationships are prohibited to it, with a stipulation that if a forbidden relationship should at any time exist the trustee must either correct the situation or resign within ninety days. ${ }^{82}$ This device permits restriction of the bill largely to the form and provisions of the indenture. To assure responsibility, every indenture affected must provide for at least one institutional trustee, ${ }^{83}$ and there may be a requirement in the indenture, if the Commission feels it necessary, that this trustee must maintain at all times a combined capital and surplus in such sum as the Commission may

79. On the extension of the public utility concept to all indenture financing, see Green, Trend of Decisions and Legislation Affecting the Corporate Trustec (1037) 15 TAX MIAG. 704, 707.

80. There is serious doubt whether abuses are, in fact, at all as general as the Bill and the REFORT state. It is generally agreed that the best trustees now maintain a high fiduciary standard. See McCollom, supra note 20, at 1212-1214; SE:inte Heirria 29-30, 149-150, 157; House Hearing 19, 21, 58, 76, 82-S4; Senate Reromt 1.

81. See Burke, supra note 71; Sexate Hearing 43, 47; Hovse Heimuo 37.

82. $\$ 308(b)$.

83. $\$ 308$ (a) (1). This would ordinarily be a commercial bank or trust company. Allowance is made for additional trustees because in some instances an individual trustee, or trustees resident in different states, would be needed to meet requirements of state law. 
determine. ${ }^{84}$ An obligation to have an institutional trustee for all isstes of any importance will meet with general favor, although the additional stipulation may be unnecessary. ${ }^{85}$

The provisions designed to eradicate conflicts of interest are less satisfactory. The bill requires every indenture of a particular obligor to have a separate institutional trustee, except in a few cases where no conflict would result. ${ }^{86}$ This may put an obligor with several outstanding isstes to some inconvenience or embarrassment to find an available high class trustee for a new indenture issue, ${ }^{87}$ but this is not a very serious objection, and the rule has precedent in its favor. ${ }^{88}$ The significant difficulty is encountered in the sections devoted to forestalling conflicts restlting from common officers or security interests. Here the definitions of what constitutes a fatal conflict of interest are worked out with a partictlarity that is bewildering: ${ }^{89}$ It is obvious that the authors of the bill, convinced

84. $\$ 308(a)(2)$. Chairman Douglas stated to the Senate subcommittee that he supposed that the inclusion of this requirement in an indenture would be insisted upon only in very exceptional cases. Senate Hearing 51.

85. The comment has frequently been made that substantial trustees are sought by issuers and underwriters to add prestige to the issue. See supra note 38 . It is, however, conceivable that persons anxious to evade these restrictions would resort to the formation and use of trustee institutions which would have no substantial assets. On the other hand, a later Commission, anxious to favor metropolitan banks, could use this discretionary power to divert trusteeship from local banks to a few selected institutions.

86. The exceptions are (1) where the second indenture is secured by securities issued under the first indenture, or vice versa; (2) where the issuer is a real estate company with substantially all its assets mortgaged, and the indentures cover distinct parcels of realty; and (3) where the issuer can prove to the Commission that no material conflict is in prospect. $\$ 308(\mathrm{~b})(1)$.

87. This point was raised at the Senate subcommittee's hearing, and the need for this provision questioned in view of the common practice of trustees to resign from one of two conflicting positions when a conflict develops. Senate Hearing 115-116. See also Stetson, supra note 6, at 20, 73; Posner, supra note 13, at 792; McCollom, supra note 20, at 1221. Resignation at the time of a default, however, may be of little assistance to security holders.

88. One of the Stock Listing Requirements of the New York Stock Exchange is that there shall be a separate trustee for each indenture under which different bond isstes of the same obligor are issued. This trustee may not be an officer or director of the issuer, or a bank or corporation either having as executive officer an officer of the issuing corporation, or controlled by, or controlling, the issuing corporation. Ancther requircment is that any listed issue must have a substantial and experienced institutional trustec. C. C. H. 1937 Stock Exch. Regulation Serv. \11617; Stetson, supra note 6, at 71-74.

89. These rules are set out in $\S 308(\mathrm{~b})$. They are too numerous and intricate for any condensed summary to be accurate. Among the more important are these: that no director or executive officer of a trustee may be a director, partner or employee of an underwriter; that there may be only one common director (a "listening post") between a trustee and an obligor, unless the trustee has ten or more directors in which case another common director is permitted; that a trustee is disqualified if it owns five per cent of the voting securities of an obligor or of any corporation which, to its knowledge, owns ten per cent of the voting securities of an obligor. It should be observed that since 1933 the Banking Acts have required the separation of commercial and investment banking. REPORT 101. 
of the dangers of influence being exerted on a trustee by an underwriter or obligor under the indenture through common directors or officers, stock ownership, or interest in some common intermediary, have systematically undertaken to sever or attenuate every conceivable connection which might draw the trustee away from its duty. Any indenture, to be qualified by the Commission, must embody these complex rules entire.

The multiplicity of these rules, their artificiality, and the low percentage of security ownership required to disqualify a trustee are characteristies which invite criticism. ${ }^{30}$ Also in their present form they will in certain cases produce anomalous consequences. ${ }^{01}$ It seems probable that one result of placing this whole code in effect would be to force trusteeships out of small town and city banks, where connections with local enterprises are frequently found, into the metropolitan banks, an increased centralization which would not be healthy.92 Then the larger the trustee bank, the more prodigious would be the task of checking and bookkeeping, and the less the likelihood of complete compliance. ${ }^{83}$ Yet it is hard not to be

90. See Posner, supra note 71, at 397; Senate Heariag 117, 134-136; House HearING 63-65.

91. For instance, a trustee is disqualified if five per cent of its voting securities is owned individually, or ten per cent is owned collectively, by the obligor or by any directors, partners or executive officers of the obligor (with one inconsequential exeeption), or if five per cent of such securities is owned either individually or collectively by an underwriter or by any of its directors, partners or executive officers. $\$ 30 \$(b)(5)$. If the trustee has voting securities which are sold in the open market, some of these persons, by buying close to the forbidden amount, could influence a trustce by threat of disqualification.

Again, these rules provide $[\$ 308(\mathrm{~b})(9)]$ that a trustee may hold in a representative capacity, such as executor or administrator, personal trustee or conservator, twenty-five per cent (and in some cases fifty per cent) of an obligor's securities, of which the beneficial ownership of five per cent would disqualify. If there is a default for thirty days in principal or interest payments under the main indenture, however, only five per eent of such securities may be held in any capacity. A default might, therefore, require the trustee to sell out individual trusts in a falling marliet at severe loss, or resign as indenture trustee at the time when its services would be most urgently needed.

92. The possibility of this is implicit in the statement of Chairman Douglas [SE:atre Hearng 55], and has been commented upon by others. See, c.g., Sexare. Heari:io 193194; House Hearing 69.

Comparable restrictions were to be found in the Lea Bill [H.R.6968, 75th Cong., 1st Sess., Committee Print No. 2 (1937)] upon the membership of protective committees. They were so numerous and exclusive in that measure that they might have cmasculated committees if not entirely prevented their formation. Dodd, supra note 42, at 254-255; Laporte, Changes in Corporate Reorganization Procedure Proposed by the Chandler and Lea Bills (1938) 51 HaRv. L. REv. 672, 681-6\$8. The Lea Bill was not acted upon by the 75th Congress; at the time of writing it has not been introduced in the 76th Congress, although its introduction has been forecast.

93. House Hearing 70. It does not appear, however, that the difficulties of bool-keeping would necessarily be insurmountable. The final judgment of the Amerienn Bankers Association, as expressed to the House subcommittee by the respective chairmen of its committees on Federal Legislation and on Afortgage Trusteeships, was that although it did not believe the bill was necessary, it considered it to be "workable, practieable, 
sympathetic with this network of restrictions, the end in view is so obviously desirable; and all these criticisms might be dismissed if there were not the more fundamental objection that a much simpler method might be more effective.

The existence of common officers, or common interests, is of course only a cause and not the evil itself. What must be prevented is the dissuasion of a trustee from the performance of its duties by some adverse interest. It is clearly impossible to root out every such connection; the important factors of family relationships, friendship and unwritten understandings all remain untouched in the Barkley Bill. Since large areas of influence will inevitably lie outside any list of prohibitions, it would seem preferable to turn from this extremely detailed regulation, with its train of minor difficulties, and to concentrate directly upon the wrongful restult.

There are ways in which a more direct attack may be made. If each trustee were subject to a formal requirement that it register with some governmental agency, and the registration could be revoked upon adequate proof that a conflict of interest had caused it to be derelict in its duty, normal self-interest should work for the solution of this problem. ${ }^{\text {th }}$ Again, where a trustee benefits itself at the expense of security holders, it may well be held liable under existing law, certainly to the extent of the benefit received. ${ }^{95}$ If .this liability were made definite by statute, and double damages provided for, a decrease in compromising connections would certainly follow.

Another provision of the Barkley Bill in fact follows this liability principle, without the punitive accessory. This is the "preferential collection" section, ${ }^{96}$ so called because of its similarity to the rule governing preferences in bankruptcy, which deals with the circumstance where a trustee, as banker, is a short-term creditor of an obligor under the indenture at the time of a default. All indentures subject to the bill must provide that in this situation any payments made to or additional collateral received by the trustee within the four months preceding the default shall be segregated and divided pro rata ${ }^{07}$ with the holders of indenture securities. If the loan was made during that period the original

and livable." House Hearing 45-47. Little attention was paid to this mechanical problem. Trustee banks, of course, could expect fair compensation for this additional work.

The largely increased fees which this bill throughout promises institutional tristces is an inducement to them, although correspondingly discouraging to issuers.

94. This is suggested by an alternative statute outlined to the House stibcommittec. House Hearing 79; see infra, p. 571.

95. See House Hearing 70. The pressure of such a liability is indicated by a case stated in the REPORT, at 84-86, where an indenture trustee which had strengthened its creditor position by correspondingly weakening the obligor restored the transferred collateral at the demand of the obligor's receivers. The usual instance would involve bad faith, or be a direct impairment of the indenture security, and this would overcome the protection of an exculpatory clause.

96. $§ 309$.

97. A complicated formula to ensure equality of division is prescribed. 
collateral also is forfeited to similar treatment unless the trustee can positively establish that at the time of the loan transaction it had no reasonable cause to anticipate such an early default. This is a residue of much more stringent restrictions in earlier drafts, to which vigorous objection had been expressed. ${ }^{\text {s }}$ It will discourage a trustee's malking "rescue loans" to help an obligor in financial trouble, and to that extent may sometimes hasten bankruptcy or make it inescapable when it might have been avoided. ${ }^{99}$ But it should be effective to block oft one clear conflict, where the trustee can secure its own creditor interest best by neglecting to take steps for the bondholders. ${ }^{100}$ This provision does not hamper the trustee's banking function unduly, and it appears as an innovation in which the chance for harm is outweighed by the possibilities of advantage. An extension of its theory to other conflicts might be profitable.

\section{The Ban on Exculpatory Ciauses}

Provisions intended to relieve an indenture trustee of liability or responsibility for action take many forms. ${ }^{101}$ There are the ever-present exculpatory clauses, both general and specific; clauses entitling a trustee to rely conclusively upon certificates or opinions of experts; clauses permitting a trustee to be considered ignorant of defaults unless notified by security holders, usually in a certain percentage; and clauses justifying a trustee's refusal to take action unless first indemnified against liability or expense and requested to act by holders of a certain percentage of the securities. These provisions have tended to become standard in the modern indenture; and under the Barkley Bill all of them, with but one exception, ${ }^{102}$ would be outlawed. ${ }^{103}$

98. See supra note 69; Senate Hearing 117-119, 125-126, 147, 158.

99. See House Hearing 49, 70.

100. See the instances where such conflicts were present, in compromising circumstances, as described in the REPORT, at 83-97.

101. See supra p. 540.

102. See $\$ 312(\mathrm{e})(2)$. The bill also permits an indenture to contain provisions protecting a trustee from liability for any error of judgment made in good faith by a responsible officer "unless it shall be proved that the trustee was negligent in ascertaining the pertinent facts," [\$312(e)(3)] and provisions authorizing the holders of a majority of the indenture securities to direct the method and place of conducting legal proceedings, with protection for the trustee in following the directions. $\$ 312(e)(4)$. Such provisions would not afford appreciable if any protection beyond that of equity and common law.

There is a new subsection in H. R. 2191, not appearing in the earlier bills, to the effect that the indenture may include a provision "that, prior to default, the trustee shall be liable for the performance of only such duties as shall be specifically set out in the indenture." $\$ 312(\mathrm{e})(1)$. This does not relieve from negligence liability, but it may have some effect in forestalling the application of the theory of "implied" duties. See supra note 27. Clauses of this general character, not limited to the period before default, are common enough in modern indentures, but if they were to stand alone, without the usual accompaniment of exculpatory provisions, they might have greater weight.

103. $\$ 312(\mathrm{e})$. There is no section which specifically bars indemnity provisions and the "ostrich clause," but it is evident throughout the sections dealing with the powers and 
The single exception is left a very uncertain one. The bill would permit indentures to include provisions authorizing the trustee to rely conclusirely, as to facts and matters of opinion, upon certificates and opinions of attorneys, accountants and experts; but this right of reliance upon other parties is to be qualified in the indenture by "such requirements as to independence and qualifications and the exercise by the trustee of reasonable care in their selection or approval, and subject to such other terms and conditions, as the Commission may deem necessary or appropriate in the public interest or for the protection of investors." Since there can be, practically, no appeal from the Commission's decision on these questions, ${ }^{104}$ it is apparent that under the bill reliance upon certificates would be largely a matter of grace rather than of right.

These protective provisions are to be supplanted in indentures by specific requirements that the trustee serve the security holders actively at all times, in accordance with the strictest fiduciary standards. The exact measure of a trustee's obligation before a default is left in some doubt, ${ }^{105}$ but the standard after default, intended to be the highest possible, ${ }^{100}$ is set out in the bill as the indenture must state it.

The effect of this part of the Barkley Bill is most difficult to calculate. As is understandable, it is regarded with greatest apprehension by officers of some trustee banks who see, in the prospect of verdicts running into millions, the fate of banks and their depositors being constantly decided by the chance and the emotion of a jury trial. ${ }^{107}$ At the other end of the scale may be found occasional comments in decisions indicating that a general exculpatory clause adds little if anything to the protection which the courts themselves would cast about an honest trustee, from which the inference is possible that discarding such provisions would not restilt in drastic change. ${ }^{108}$ The actuality lies between these two extremes.

duties of trustees that such provisions will not be permissible unless the enacted bill should be administered contrary to its present interpretation and tenor. House HestING 21; see also $\$ 312(a)$, (b).

104. See infra, p. 563.

105. The trustee is to have such duties as "are consistent with the duties and obligations which a prudent man would assume and perform prior to such a default if he were trustee under such an indenture . ..." [\$312(a)]; see infra, pp. 557-560.

106. $\$ 312(\mathrm{c})$. "The indenture to be qualified shall contain provisions requiring the indenture trustee to exercise in case of default (as such term is defined in the indenture) such of the rights and powers vested in it by the indenture, and to use the same degree of care and skill in their exercise, as a prudent man would exercise under the circumstances if he were a fiduciary and had the degree of skill which the indenture trustec has, or which, at the time of the offering of the indenture securities, the indenture trustee represents itself as having, as indenture trustee, whichever is the higher." The purpose of this elaborate circumlocution is, evidently, to push the standard of care up as high as it can possibly go. Anything further would make the trustee an insurer.

107. Senate Hearing 124-128, 139-140, 146. House Hearing 51-52, 61, 66.

108. See Riker v. Alsop, 27 Fed. 251, 259 (C. C. S. D. N. Y. 1886); Watson v. Scranton Trust Co., $240 \mathrm{~Pa} .507,512,87$ Atl. 845, 847 (1913) ; Cassels, The Effect of Indcm- 
Since a trustee's liability will be directly related to the extent of its duties, this subject should be divided into the time before a serious default and the time after, for each period has its particular demands. Once a default of real consequence has occurred, the obligation of a trustee is perfectly clear. It must spare no reasonable effort to make certain that the default is properly cured or, if not, that the security is fully realized upon for the benefit of the holders of the indenture securities. This basic duty of the trustee would probably not be altered materially under the Barkley Bill, although a few additional powers might be given, and all excuse for inaction would be removed. Obviously no one but the trustee is or can be expected to be in a position to act effectively when the emergency arrives. Security holders are usually scattered and unorganized, and their organization, when it is perfected, may not be adequately equipped and is seldom completely representative. To allow each individual holder of a bond or debenture to bring his own suit would result in confusion. The original business intention was to place the trustee in its focal position for this purpose, among others, and no convincing reason appears why a trustee should not be under a liability for ordinary negligence in the performance of its most important active function. Little would be gained, however, by raising the standard still further, as the Barkley Bill seeks to do $;^{109}$ this added imposition seems confusing and unnecessary. ${ }^{110}$

It has been pointed out ${ }^{111}$ that one result of withdrawing the protection of exculpatory clauses would be to oblige the trustee to enter and foreclose or to institute reorganization proceedings immediately upon a default, to escape any imputation of negligence or chance of liability for loss attributable to its delay. Very likely this would follow, and also there is little question that a trustee's willingness to forego the strictest measures, to give the obligor a chance to right itself after a default in interest or principal payments, has on occasions in the past been directly instrumental in avoiding bankruptcies and consequently highly beneficial to security holders. This occasional benefit will be lost, if liability for negligence is imposed, and the only answer to this objection is that a trustee's willingness to wait has at times worked the other way. But the argument brings out one point of great importance; if the system should be so changed that technical and relatively trivial defaults might precipitate entry or foreclosure, ${ }^{112}$ indentures would be such dangerous instruments

nity Clauses upon Trustecs' Liability for W'Filful Default and Neglect (1889) 9 Car. L. T. 1.

109. $\$ 312(c)$.

110. Senate Hearing 114-115; House Hearing 51.

111. Senate Hearing 127-128; House Heiring 51-54, 50. 66.

112. An effort to prevent this result is evident in the seetions of the bill giving the Commission power to determine what shall constitute a default, what particular defaults shall require notice to security holders, and rights and powers of the trustee in respect 
that their use might be abandoned by issuers. As any default at all would appear alarming to a trustee liable for negligence, there is perstasive reason for restricting that liability to the period after an important default. Other considerations lead to the same conclusion.

The typical modern indenture contains not only a varied list of obligations of the trustee, to be performed from time to time, but also numerous intricate covenants of the obligor. During the normal life of the trust characteristic duties of the trustee, already referred to, are to authorize the substitution of security or to release it for sale, to authenticate and deliver additional indenture securities and to ascertain the proper application of their proceeds. Substitution, release and the further issuance of securities are acts usually permitted by the indenture only if certain conditions are satisfied. The condition precedent most frecutuently found is that the issuer shall have performed all of its covenants to that time. There are often special conditions for particular acts: substituted security may be required to have a certain value $;^{113}$ the right to have more securities issued under the indenture may depend upon the acquisition of new property or construction of new facilities in accordance with detailed specifications. ${ }^{114}$ If the trustee were to be held personally responsible for seeing that such conditions were met, it would have to exercise a high degree of supervision over the issuer's business. To ascertain whether or not a default existed somewhere might require under some indentures ${ }^{115}$ a thorough analysis of the obligor's capital structure and present position, including an appraisal of its assets. Indentures now short-cut these enormous complications by permitting a trustee to rely upon certificates and opinions of experts or officers of the obligor, and exculpatory clattses protect the trustee, at least to some extent, in this reliance.

The Barkley Bill would work a complete change. The right to obtain protection through reliance upon certificates would surely be restricted and might for all practical purposes be substantially eliminated.119 As

to foreclosure and sale. $\$ 312$ (b), (d) (1), (d) (2) (c). The trustee's right to petition for instructions is probably too limited to be of any practical assistance here. Sce Posner, supra note 6, at 203; McCollom, supra note 20, at 1209; Hill v. Moors, 224 Mass, 163, 165, 112 N. E. 641, 642 (1916); City Bank Farmers Trust Co. v. Smith, 263 N. X. $292,295,189$ N. E. 222, 223 (1934).

113. When the substituted security is to be stock or bonds of another corporation, the earnings or assets of such corporation may have to equal a certain figure, and the formula of computation may be very involved. See REPORT 16, 19, 27.

114. See Rhinelander v. Farmers Loan and Trust Co., 172 N. Y. 519, 65 N. E. 499 (1902) ; REPORT 27.

115. For example, indentures obliging the issuer to maintain a certain ratio of quick assets to liabilities, or to refrain from encumbering a certain percentage of its property. Clauses such as these are commonly used to strengthen the credit of unsecured debentures. Stetson, supra note 6, at 66-67; Dewing, A Study of Corporation Secukities, Thitik Nature and Uses in Finance (1934) 314.

116. It is interesting to observe in this connection that although H. R. 10292, 75th Cong., 3d Sess. (1938) would have permitted a trustee to rely in some circumstances 
this right is curtailed, the trustee's duties become correspondingly increased; if it can no longer depend upon the word of an accountant or a company officer, it must itself, whenever called upon to act, make an independent investigation to determine whether the specified conditions precedent to its action have been completely satisfied. The item of expense involved in a single investigation of this sort might be very substantial, and if such investigations were necessary at intervals at all corresponding in frequency to the present use of certificates, the expense alone, charged to the issuer, would be a heavy burden upon it. There would be another burden upon the issuer as well, that of the trustee's constant supervision and interference. A careful trustee, acting under the provisions of the Barkley Bill, would probably feel obliged to maintain close contact with an obligor's business affairs, for fear that if some situation affecting the indenture escaped its attention the liability for negligence, imposed throughout this new activity, would expose it to risk of suit and possibly large damages. An issuer might find that in many business decisions the trustee's approval would practically be necessary; and its word final.

The work of an indenture trustee must be kept within reasonable bounds if this method of financing is not to become so expensive and cumbersome as to be useless. The present custom of permitting reliance upon opinions and certificates, with the addition of exculpatory clauses for what additional protection they offer, is far from perfect, yet it is preferable to the alternative the Barkley Bill presents. It would be an improvement if certificates of independent experts could be assured, ${ }^{117}$ but it is difficult to see any practicable way in which reliance upon certificates can to any considerable extent be displaced. Nor is the extension of the trustee's responsibility, by eliminating protective devices, a remedy which may be too freely administered. The balance favors leaving the trustee with his present protection against negligence litigation unless and until a serious default occurs. ${ }^{118}$

There is another important reason why a trustee's liability should not be so largely extended. It is obvious that removing all protection from a trustee, as well as greatly increasing its duties, will necessitate the charging of far higher fees for the acceptance and execution of the trust. At present the ordinary indenture trustee has no need of a sizeable staff of accountants, appraisers and engineers, and the fee it charges is relatively very small indeed, commensurate with the ministerial character

upon certificates of officers of the obligor, that possibility is eliminated in the present bill.

117. The meticulous requirements suggested and authorized by $\$ 312(e)(2)$ appear to go much too far.

118. This is the view of Mr. Posner. Senate Hearing 113. 
of most of its functions. ${ }^{119}$ How much of an increase would be needed to compensate for all the added responsibilities contemplated is wholly speculative, but it could not fail to be a very substantial one. ${ }^{120}$ This emphasizes a characteristic which the Barkley Bill shares with other regulatory legislation, that it will bear hardest on the small or struggling issuer, without much margin in the flotation of its securities, while the well entrenched corporation would feel its incidence less. If the liability for negligence were restricted to the time after a significant default, the increase in fees would be far less marked, and the transition would be less difficult, not only for trustees but for issuers, whose interests deserve much more attention than they appear to have received.

\section{Authority of the Securities and Exchange Commission}

Overshadowing in importance all the rest of the Barkley Bill are the sections which confer upon the Securities and Exchange Commission virtually unrestricted authority to prescribe most of the terms of the corporate indenture. The contemplated transfer of power over private contract from private hands to a federal agency is so complete as to provole a general controversy of political theory having, however, only secondary importance to the problems of the trust indenture.

119. A corporate trustee in New York City, acting as trustee for a $\$ 10,000,000$ indenture issue of 4 per cent 20-year mortgage bonds of $\$ 1,000$ denomination, would charge, for the initial and final services of acceptance, certification of temparary bonds (in large denominations) and definitive bonds, cremating the bonds and payment of principal, approximately $\$ 9,000$. Its annual fee for normal services in connection with the issue would be $\$ 500$, and if it acted as paying agent there would be an additional annutal charge of $\$ 1,000$. Cremation of all coupons would add $\$ 200$ annually, and for other services in connection with holding stock and bonds as collateral, sinking fund, conversion, registration, executing supplemental indentures, etc., small specific fees would be charged. Corporate Fiduciaries Association of New York City, Schedule of Fecs, November 8, 1933. The statement of Justice Rosenman in Hazzard v. Chase National Bank, 159 Misc. 57, 287 N. Y. Supp. 591 (Sup. Ct. 1936) that the trustee's fee was "grotesquely exorbitant in view of the negligible services performed" was colored by the circumstances of that case and is not generally applicable. By way of comparison, though not as a criterion, the statutory fee of a personal trustee in New York for managing a trust of mixcd property of $\$ 10,000,000$ principal value, yielding 4 per cent, would be $\$ 200,020$ plus an annual charge of $\$ 8,020$. Ibid. In Boston the comparable charges for the indenture trustecship would total substantially the same as those of a New York trustce, but for the ficrsontal trust the trustee's fee would be $\$ 105,000$ plus an annual charge of $\$ 24,000$. In Philadelphia the indenture trustee would charge somewhat less for similar services, and the personal trust fee would be $\$ 204,000$ plus an annual charge of $\$ 12,000$. See Schedule of Fecs for Personal Trust Services and Services to Corporations in Pennsylzania, effective December 9, 1933. A schedule of comparative fees is annexed to the RErokr as Appendix B.

120. See Stetson, supra note 6 , at 52; McCollom, supra note 20 , at 1204-1205, 12271228; Report 69-70; Senate Hearing 139, 160; House Henring 52, 68. 
The reasoning which led to fixing the bill in this form is simple to follow. ${ }^{121}$ Briefly, it is that the faults of the modern indenture pervade every part, and if outlawed in one place or form they might well recur in another; that any set of rigid rules would be impracticable, because indentures should and do vary widely to meet individual requirements; that the investors, who have borne the consequent losses, are not in a position to exert any real influence; and that therefore an arm of government must be endowed with flexible powers, as a representative of the investors, to correct defects in indentures wherever they may occur. In outlining these powers it was found desirable, in view of the omnipresent possibility of defective or stultifying provisions, to have them cover practically the whole substance of the indenture. Although the intention was that in practice these powers would be exercised only in part or accasionally, a broad original definition was needed to insure an adequate reserve for unforeseen contingencies. So far as possible. however, it was planned that the purely "business" features of the indenture contract should be excluded from the sphere of governmental control.

The present form of the Barkley Bill shows the difficulty encountered in attempting to restrain a measure built upon this logical basis. Changes from the earlier drafts afford additional indications. ${ }^{122}$ There is, of course, no way of granting a power which is complete and all embracing, yet limited by some assurance that it will be sparingly used. That assurance may be implicit in the character of an administrator, but it is necessary to look beyond individuals in analyzing this proposed law.

There can be no doubt as to the extraordinary extent of the Commission's powers under this bill. No indenture is to be acceptable for qualification unless it contains provisions which the Commission "deems adequate" prescribing the rights, duties and powers of the trustee, the

121. See, generally, SeNate Report and the exposition of Chairman Douglas before the Congressional committees, Senate Hearing 17-87; House Hearno 16-43.

122. The first two committee prints, for example, provided that the Commission could exclude from indentures any provisions "the elimination of which is necessary or appropriate in the public interest or for the protection of investors or to prevent the circumvention or evasion of this Act" [\$6(5)], and the phrase employed in connection with the Commission's power to prescribe certain other groups of clauses was "The indenture to be qualified shall contain such provisions as the Commission shall deem necessary or appropriate in the public interest or for the protection of investors." $[\$ 7(m)]$. In the third committee print the first of these provisions was modified by dropping the word "or" before "to prevent," and the second provision was generally altercd to "The indenture to be qualified shall contain provisions which the Commission deems adequate, having due regard to the public interest and the interest of investors." The present measure eliminates from the first clause the words "or appropriate in the public interest or for the protection of investors," but makes no further alteration in the second provision. $[\$ \$ 307(5), 312(d)]$. These changes were clearly intended to limit the Commission's discretionary power, but it is doubtful how much limitation was actually effected. See also note 123(10) infra. A successful restriction is found in the present $\$ 316(a)$. Sce infra note 128 . 
obligor, and even the security holders in connection with almost every subject which the modern indenture touches. ${ }^{123}$ On some of these sub-

123. The most important of these required provisions which the Commission has the power to prescribe, in a form it considers appropriate, are those defining

(1) the trustee's duties after default, comprising the subjects of entry, foreclosure and sale, obtaining judgment, appearance and intervention in judicial procecdings, filing proofs of claim and calling meetings of security holders $[\$ 312(c),(d)(2)]$;

(2) the "rights, powers and remedies of the indenture security holders and the manner in which and conditions upon which such rights, powers and remedies may be exercised" [\$ 314] ;

(3) the "qualifications, rights, powers and duties of paying agents" $[\$ 315(a)]$;

(4) restrictions and conditions upon the release and substitution of security, thic issuance of additional indenture securities, and satisfaction and discharge [\$313];

(5) what shall constitute a default under the indenture [\$312(d)(1)];

(6) the duty of the trustee to notify indenture security holders of such defaults as the Commission considers of sufficient importance $[\$ 312(\mathrm{~b})]$;

(7) requirements for compiling and keeping lists of indenture security holders, and making these lists available to security holders upon conditions which the Commission "deems not detrimental to the public interest or the interests of investors" [ $\$ 311]$;

(8) requirements for such annual and other reports from the obligor and the trustee, upon a great variety of subjects, as the Commission may from time to time prescribe by rule and regulation, the reports to be transmitted or made available to security holders as the Commission's rules may require $[\$ 310]$;

(9) restrictions upon the employment by the trustee of attorneys or experts laving possibly conflicting interests, and requirements as to independence and qualifications of experts furnishing certificates [ $\$ 312$ (e) (2), 315(b)] (see supra, p. 559); and

(10) The provisions prescribing the trustee's duties before default. These provisions are, however, now given somewhat different treatment. The final form of the bill in the 75th Congress would have required the indenture to impose upon the trustce such duties before default "as the Commission deems consistent with the duties and obligations which a prudent man would assume and perform prior to such a default if ho were trustee under such an indenture, including, without limitation, action in respect of "(a) recordation, (b) the application of proceeds, (c) "the existence of or compliance with" all conditions precedent to authentication and delivery, the release and substitution of security, satisfaction and discharge, and "any other action by the trustee unuler the indenture," and (d) "the performance by the obligor of such of its other obligations under the indenture as the Commission deems necessary or appropriate in the public interest or for the protection of investors" [ $[\$(\mathrm{~g})]$. A theoretical restriction on the scope of the Commission's discretion is established by the present bill, in which the phrase "the Commission deems consistent" is replaced by "are consistent," the rest of the section remaining unaltered $[\$ 312(a)]$. Since the Commission in any event has power to prescribe the form of these indenture provisions (see note 128 , infra), the practical effect of this change may be only to give a slightly better basis for an appeal from the Commission's decision in the rare case where an appeal would be practicable.

Compare the grant of discretionary power to the Commission, to prescribe the terms of solicitations by committees, provided in the I.ea Bill, H. R. 6968, 75th Cong., 1st Sess., Committee Print No. 2 (1937), supra note 92; Laporte, supra note 92, at 684-687. The Lea Bill, the Chandler Act [52 Stat. 840, 11 U.S.C. \$1 (Supp. 1938)] and the Barkley Bill should be given joint consideration: all three extend administrative supervision or control over functions of business and share a purpose to make more strict the standards of business conduct. See Weiner, The Securitics and Exchange Commission and Corporate Reorganization (1938) 38 CoL. L. REv. 280, 286-288; Laporte, supra note 92 , at $673-674$. 
jects the Commission's power to create indenture clauses appears to be altogether unlimited, unless by the indefinite influence of the introductory section. ${ }^{124}$ On others identifying references of a very general sort are found: for example, in one section the bill, in connection with the important acts of releasing or substituting property, issuing new securities and satisfying the indenture, authorizes the imposition of "restrictions and conditions which, in the light of the bargain of the parties, the Commission deems adequate, having due regard to the public interest and the interest of investors." ${ }^{25}$ Phrases of this character, although disclosing a desire and effort to bound the Commission's discretion, ${ }^{120}$ have little if any practical force. Should anything further be needed to perfect the control of the Commission, it is supplied by two additional clauses, one barring from indentures any provision which limits, qualifies or conflicts with any required provision or which should be eliminated to prevent deception, circumvention or evasion, ${ }^{12 \pi}$ and the other empowering the Commission to determine the wording of any provision which an indenture must contain. ${ }^{128}$

The Commission's discretion in these important matters is not only virtually unlimited, but it is also as a practical matter absolute and unreviewable. It is true that there is an appeal provision, ${ }^{120}$ incorporating the jealous rule of the Securities Act that on appeal the Commission's findings of fact, if supported by evidence, ${ }^{130}$ shall be final; but the bill is so worded that the only question available for an appeal in connection with these required provisions would be whether the Commission in any case properly deemed the provision "adequate", "consistent" or "necessary and appropriate" for the end in view. Constitutional questions might be raised in the extreme case, but the delay in obtaining a final decision would normally render such litigation useless.

The effect upon business of the actual administration of this part of the bill is, of course, unpredictable. If the Securities and Exchange Com-

124. The provisions defining the rights of security holders seem to be entirely within the Commission's discretion. See $\$ 314$.

125. $\S 313$. See also $\S 302(5)$. The reference to "the bargain of the parties" appears for the first time in the third committee print. Before its inclusion Chairman Douglas said that the Commission might "conceivably, in some cases, not allow substitution at all." Senate Hearing 39. The change was made to show a restriction of that power. Seasite HEARING 213.

126. The words "having due regard to the public interest and the interest of investors" are repeated in substantially all the sections of the bill which confer discretionary powers.

127. $\S 307(5)$.

128. $\$ 316(a)$. In earlier drafts of the bill this power extended to various provisions "required or permitted to be included in an indenture," but in $F . ~ K .2191$ the words "or permitted" do not appear.

129. $\$ 319(\mathrm{a})$.

130. Wholly insubstantial evidence, however, would presumably not suffice. $C f$. Consolidated Edison Co. v. N. L. R. B., 59 Sup. Ct. 206 (U. S. 1938). 
mission desired, it could use these broad powers so conservatively and so seldom that indenture financing as a whole would hardly be affected. On the other hand, if the Commission were antagonistic to corporate business, it could employ this discretionary authority literally to make indenture financing impossible. ${ }^{131}$ Between these extreme positions, neither of which is immediately probable, lie innumerable degrees of interference and assistance. The experience of no one issuer will necessarily be duplicated by another, since each indenture can be the subject of individual rulings. ${ }^{132}$

It has been stressed by the sponsors of the Barkley Bill that it cloes not give the Commission any control over such business fentures of an indenture as interest rate, maturity date, amount of security, sinking fund provisions and the like. ${ }^{133}$ There was some doubt, when the bill was first made public, whether or not these subjects were also intended to be brought within the discretionary powers, for though not expressly mentioned they might, by strained construction, be included. ${ }^{131}$ At the hearings, however, Chairman Douglas stated expressly that the determination of these "business" matters was intended to remain a private concern, that the bill dealt only with the "non-business" provisions of an indenture.

It is unfortunate that the exclusion of these subjects has not been made explicit, ${ }^{135}$ for at best the distinction is a difficult one to maintain. In several places the bill appears to touch "business" subjects; for example, the release and substitution of security is as much a business matter ${ }^{130}$ as provisions for a sinking fund, and where the line is supposed to be drawn remains in doubt. It is also open to question whether a permanent line is intended; one cannot be sure how long a conservative interpretation would satisfy future administrators. The framework of the bill, excepting the introductory section, would be weakened with less control; but it could easily accommodate more control, and the measure looks in

131. It would be not at all unreasonable to discuss the Barkley Bill from the viewpoint that it is intended to control, retard or perhaps eventually eliminate the dircet flow of private capital into private business and industrial enterprise. It might be used for that end, and it may receive some support for that reason; but as Chairman Douglas expressly and vigorously disclaimed any such intention before the House subcommittce [Housi: Hearing 31,32$]$ that view is not a subject for consideration in this article.

132. See House Hearing 34.

133. See Burke, supra note 71; House Hearrig 19, 22.

134. See Hausserarann, Proposed Federal Trust Indenture Act la lecture delivered before the Investment Bankers Conference, Inc., New England District, at Boston, Mass., December 29, 1937, privately printed] 9.

135. This opinion was urged before the subcommittee of the House in April, 1938. House Hearing 59-60. But no change in this respect is made in the present measure.

136. Negative pledge clauses afford another example. Their inclusion in an inclenture was spoken of by Chairman Douglas as "a matter of business judgment." Sinste: Hearing 31. 
that direction. An amendment specifically embracing business elements could be easily made. Since the Commission, in determining what constitutes a desirable indenture, offers to assume the exercise of what is essentially investment judgment, there would be no real point of principle involved, so long as investors continue to suffer from their own or others' improvidence, in seeking control over many other matters which for the time being are left to private determination. The theory of the bill is so broad that successful defense against a further extension of pover is made very difficult.

Without any extension, however, the Barkley Bill essentially supplants private control of indentures with governmental control. The actual drafting of most of the indenture is subjected to the conclusive authority of a federal agency. This offers two possibilities of advantage: it creates an opportunity for the investor's interests to be represented more directly than heretofore, and it promises to jolt indentures out of the rut which generations of harassed draftsmen have worn. There is substantially unanimous agreement that some common indenture provisions should and can be strengthened in the investor's favor. There is also complete dissatisfaction with the exaggerated complication and length of the modern instrument.

An expert, impartial study of the typical indenture could undoubtedly improve and simplify it in some degree. But the task is imposing, ${ }^{137}$ and it requires the highest technical competence. Such a study would be severely if not fatally handicapped by the pressure of having its day-today conclusions actually determining the course of very important transactions. ${ }^{138}$ It is not detracting from the excellent record and accomplishments of the Securities and Exchange Commission, with its past and present membership, to express doubt whether any governmental agency, constituted as the Commission is and carrying such a heavy burden of duties, could possibly discharge such work effectively without making some very costly errors.

The corporate indenture is not a fair field for experiment; a mistake can have very serious consequences. Indentures not infrequently remain in force twenty, thirty or fifty years, and any misstep which the Commission might make in fixing an indenture's terms would affect the parties to it for the whole time, ${ }^{130}$ unless the securities could be called or

137. See Stetson, supra note 6, at 25-27; Drinker, supra note 37.

138. The six-month' grace period between enactment of the bill and its effective date would permit some of the preliminary work to be completed, but to espect, as Chairman Douglas has intimated, that a workable set of principles and rules could be worlied out in that period seems much too optimistic. See House Henrric 35, 85, 89, 90.

139. This point was raised at both the Senate and the House committee hearings. Sc:ate Hearing 142; House Hearing 76-77. In reply Chairman Douglas said that any unworkable provision could be taken care of by later amendment of the indenture. House Hearing 35. But since a simple way to escape the whole force of the act would be to provide an easy amendment procedure, it is obvious that the Commission would leep 
the indenture amended. That some errors would occur is a human certainty, as appears when some of the subjects to be affected by rulings are considered.

Self interest of draftsmen does not explain the failure to solve a number of important problems of the indenture. The reason is found in their inherent difficulty, generally enhanced by the necessity of adapting the instrument to the statutes and decisions of many jurisdictions. No fully satisfying answer has been given to these key questions:

How far should individual security holders be able to enforce the security contract? If every holder of a bond or debenture could stue in his own right for the principal sum immediately upon a default, ${ }^{140}$ that event might produce a race of diligence between hundreds of plaintiffs. The confusion would be heightened if an individual right to realize upon the security were granted. ${ }^{141}$ For the protection of the security lolders themselves a restraint on such action must be imposed, yet too great a restraint may place a minority at serious disadvantage. ${ }^{142}$

To what extent should lists of security holders be maintained and made available? It is obviously undesirable to have such a list controlled by

strict watch on amendment provisions with a view to keeping the indenture as approved intact. Also if an indenture can be amended too easily its protective features are wealsened, and the marketability of the securities may be affected.

140. The right to sue at normal maturity is much more generally accorded by decisions, and by the indentures themselves, than the right to sue upon the acceleration of maturity by default. Posner, supra note 13 , at 774-775. Either right, however, is a mutter of some controversy. Certain rights the security holders in any event retain: they may sue to prevent impairment of the security, and they may in certain circumstances obtain the removal of the trustee. Posner, supra note 13, at 776-778; Jones, supra note 34 , at 20-21.

One definite step is taken in the bill towards increasing the individual rights of the security holders. $\$ 314$ would forbid the inclusion in a qualified indenture of any provision permitting, with or without the consent of a percentage of security holders, reduction in principal, postponement of maturity, or postponement of interest payments for more than a year. The object of this provision is to bar "voluntary reorganizations" and to force all rearrangements of indenture debts, unless one hundred per cent consent is obtained, to be made by a bankruptcy or equity court. See House HEARANG 35. Thic criticism of this provision [see Senate Hearing 161; House Hearing 49-50, 74] jllustrates the conflict of theories on this general subject.

141. See Batchelder v. Council Grove Water Company, 131 N. Y. $42,46-47,29$ N. E. 801-802 (1892).

142. In Allan v. Moline Plow Co., 14 F. (2d) 912 (C. C. A. 8th, 1926) the Batchclder case, supra note 141 , was cited to sustain the exclusive operation of a similar curb against a noteholder suing at normal, not accelerated, maturity, even though the acceptance by ninety per cent of the noteholders of a voluntary reorganization plan made compliance with the requirement impossible. This decision was criticized in the REpont, at 62-63, and conflicting decisions show the variety of opinions held. See (1927) 27 Cot. L. Ruw. 443, 579; (1931) 41 Yale L. J. 312, 774; (1935) 33 Mich. L. ReV. 604; (1935) 83 Ut. OF PA. L. Rev. 679.

Holders of indenture securities have a fiduciary relationship inter sese which courts have recognized. Linder v. Hartwell R. R., 73 Fed. 320 (C. C. N. D. Ga., 1896); Stetson, supra note 6 , at $45-46$. 
an issuer or underwriter interested in concealing or minimizing a default, or in controlling a reorganization to its own advantage. But it would be equally unfortunate if a list were made easily available to irresponsible parties or trouble-makers. ${ }^{143}$ It is difficult to see how any rule, no matter how ingenious, written into the indenture could replace the exercise of individual judgment in avoiding unscrupulous use and yet permitting proper access. ${ }^{144}$

What defaults should a trustee publish or make known to security holders? It is evident that heedlessly giving publicity to unimportant or inadvertent defaults could do great damage to an issuer and to the holders of its securities, impairing its credit and depressing security values. ${ }^{135}$ On the other hand there are some defaults which should not be kept secret. It would appear almost impossibly difficult to draw this line accurately in advance, and the authors of the bill may not have contemplated any precise distinction being made, ${ }^{140}$ but the bill itself gives widest latitude. $^{1 * \pi}$

What ordinary indenture provisions are truly misleading and deceptive, or against public policy? The example frequently given is that of the negative pledge clause. ${ }^{148}$ The Commission appears to hold these clauses in particular disfavor, and certainly there have been cases where faulty provisions have allowed substantial evasion under cover of technical compliance. ${ }^{149}$ Remedies are unsatisfactory and uncertain. ${ }^{150}$ But the negative

143. Such lists are useful "sucker lists" for salesmen of doubtiul sceurities, and their availability would facilitate "strike" litigation of all kinds.

144. The opposition of views on this subject is well illustrated by the testimony of two witnesses before the Senate subcommittee, one advocating easy access, the olher greater restriction. Senate Hearing 94-97, 154-156; see also Senate Heinisg 63-64, 110, 157158; House HeARING 66-67.

The Commission might decjde, of course, to leave the matter in the diseretion of the trustee, but it seems much more probable that some specific regulation would be tried. Section 311 requires indentures to contain adequate provisions for keeping the trustee informed of the names and addresses of the security holders, and obliging the trustee "to make such information or the use thereof available to indenture security holders, subject only to such terms and conditions as the Commission deems not detrimental to the public interest or the interests of investors."

145. Posner, supra note 13 , at 763-764.

146. A rough division could, of course, be marked out, say between defaults in interest and principal payments and all other defaults, but the Commission might wish to go considerably beyond this in many instances. See Sen.ute Hearivg 68-69; House Hennivic 40. Again there are here two schools of thought. See Sex.tTe Heirixc 99-101, 110-111, 155-6, 159; House Hearixg 40, 66-67.

147. $\S 312$ (b).

148. Senate Hearing 82: Senate Report 13.

149. REPORT 10-16. At page 15 it is said, "There can be no doubt that the problem is primarily one of control over the issuer rather than the trustee." The bill, however, relies upon control of the trustee which in turn is to supervise the issuer.

150. See Jacob, The Effect of Prozision for Ratable Protection of Debenture Holders in Case of Stubsequent Mortgage (1938) 52 Hinv. L. Rev. 77; Comments (1935) 30 InL. L. REv. 487, (1936) 46 YALE L. J. 97; (1936) 49 HARv. L. Rex. 620. The case of Kelly 
pledge clause is not intended to give a debenture the full measure of security which a bond may have. It is one of the various intermediate devices which expand the field of financing, enabling an issuer in particular circumstances to utilize its assets to its best advantage in the money market. Instances of evasion, which have not been shown to be more than occasional, ${ }_{151}$ are insufficient reason for condemning altogether a type of clause which serves in general a useful purpose. ${ }^{162}$

What degree of supervision over an obligor's affairs may reasonably be required of a trustee? This is one of the most important questions raised by the Barkley Bill, one on which opinions diverge and the possibilities of error are apparent and serious. If, as the bill proposes, the trustee's fear of liability is to be the primary guarantee of the good behaviour of obligors, then the theoretically complete answer is to make the trustee responsible for superintending everything which an obligor should or might do touching his duties and obligations under the indenture. $^{153}$ But this would make indenture financing onerous and expensive to the point of impossibility. ${ }^{154}$ An obligor might find itself attended and scrutinized by the trustees' accountants, engineers and business advisers at every turn. The development of indentures shows a very slow and cautious extension of the trustees' responsibility in this direction, and although some further increase might well be salutary it should be planned with very careful and accurate judgment.

These questions and many others ${ }^{155}$ would, under the Barkley Bill, be determined for each subject indenture by the Commission alone. Every

v. Central Hanover Bank \& Trust Co., 11 F. Supp. 497 (S. D. N. Y. 1935), discussed in the REPORT at 13-15, was appealed to the Circuit Court of Appeals, but the litigation was compromised before a final decision was reached. The Circuit Court of Appeals' decision published in 85 F. (2d) 61 (C. C. A. 2d, 1936) was later modified upon petition for rehearing, and, as modified, it did not reverse the lower court but ordered the cause to be remanded for further findings, the appellate court meanwhile retaining jurisdiction of the appeals. Since the compromise interrupted the litigation at this point, the case is of little value as authority on the legal questions involved.

151. See House Hearing 88.

152. The disclosure provisions of the Securities Act of 1933 to some extent constitute a check upon defective negative pledge clauses. See supra p. 547. The Commission's suggestion that these clauses be totally eliminated has, however, received some support. See Posner, supra note 13, at 759; McCollom, supra note 20, at 1233.

153. Until the Commission should actually undertake to prescribe indenture provisions under the bill one cannot say whether it would in fact require supervisory duties to be stretched to a prohibitory extent; but the danger that practice might be sacrificed to theory is emphasized by features of the Lea Bill, sponsored by the Commission, which, in attempting to provide particular protection, encounters and creates practical difficulties which may well render the measures wholly unworkable and defeat the end sought. Laporte, supra note 92; Drinker, The Effect of the Lea Bill on Non-Judicial Rcorganisations (1938) A 2 Corp. Reorg. \& AM. BANkr. Rev. 5.

154. See McCollom, supra note 20, at 1224 et seq.; Stetson, supra note 6 , at 52.

155. See supra note 123. 
situation requiring special provisions would, in theory, receive an individual ruling. But referring these intricate problems to an agency of government will not necessarily bring about their solution, and it raises another difficulty. If, in a search for a new balance of interests, or for any other cause, some entirely impracticable indenture provisions should be insisted upon, an issuer could have no relief elsewhere. There could be no appeal to the courts, or, for immediate help, to Congress or legislative representatives, except for possible pressure through political channels. The financial community could offer no direct assistance. The experience and special knowledge of the obligor's officers and counsel might have little weight when matched against a Commissioner's personal conviction. The risk is a real one. There is as yet much too short an experience with agencies of this character in our national government to be at all sure of a tradition of restraint.

But the possibility of unwise or unworkable provisions being required by a Commission is not the only objection to this phase of the Barkley Bill. The total uncertainty in which the measure would place future indenture financing is very disturbing to contemplate. Some forecast of the present Commission's wishes can be made after a study of the Report and the record of the hearings, but on many important matters there is no substantial indication what requirements would be fixed. The day the bill should become law, no one could be sure what terms future indentures would have to contain, what duties a trustee would have to undertake, or on what conditions additional bonds under outstanding indentures could be issued. This uncertainty would to a lesser extent be renewed with each change of Administration and each major shift of Administration policy. The depressive and deterrent effect of this condition would, especially at the start, be considerable. ${ }^{100}$

While moderate and skilful administration of the bill's provisions, if it were enacted, could allay doubts, it could not dispel them. The Barlley Bill is planned as a permanent law, to be administered by a succession of public officials whose standards, abilities and political philosophies are wholly conjectural. It is possible that the Securities and Excliange Commission may become what each successive administration chooses to make ${ }^{\text {it, }}{ }^{157}$ and it is unlikely that it will always be completely free from par-

156. The practical undesirability of having uncertainty overhang underwriters and issuers of securities was recognized by the present clairman of the Commussion, writing, before his appointment, on the Securities Act of 1933. Douglas and Bates, stlpra note 56 , at 173, 189-192, 211, 214.

157. The five Commissioners are appointed for staggered five year terms [Securities Exchange Act of 1934, 48 STAr. 881, 15 U. S. C. $\$ 78$ (1934), $\$ 4(z)$ ], so that any administration after three years would have at least three appointments, without taling into account resignations. The Act provides that "Not more than three of such commissioners shall be members of the same political party, and in maling appointments 
tisanship or incompetence. Indenture financing is vital to a good part of our nation's major business enterprise. An incompetent administration of this measure could cause in a short time far greater losses than those for which the present practice may be responsible. Partisan and discriminatory administration could have even more serious results. The bill affords a punitive weapon far more effective than the tax investigation. Thousands of corporations now have outstanding issues of indenture securities, and maturities with their need for refunding operations are constantly impending. In turn these corporate obligors would each be required to satisfy a single agency with unreviewable discretion, its members necessarily responsive to the Administration then in power. It is paradoxical to assume that incompetence and partisanship are frequently found in the business and financial world, and yet to ignore the possibility of their appearance in an agency of government.

If increased control over business by the Administrative branch of the federal government is the primary aim of the Barkley Bill, then there is no real reason for changing it. But if the desire is solely to remedy fatilts in indenture financing, the constructive results of this measure would be realized at much too high a price in constant instability, unnecessary dislocation and possible lasting damage.

\section{ConcLUSTON}

The Barkley Bill, and the Report upon which it is founded, have already performed a service. They have made prominent the faults of the present system of corporate indentures, and they have stimulated a general and energetic exploration of all its aspects. If it would be unfortunate to have the Barkley Bill enacted in the present form, it would be equally unfortunate if substantial improvement by some means were not achieved.

It may be that the defects of the present practice can be largely remedied by voluntary organization and study in which underwriters, issuers

members of different political parties shall be appointed alternately as nearly as may be practicable," but the influence of this requirement may not be substantial.

In all probability a President could, if he wished, force the earlier retirement of a Commissioner with whom he was in disagreement. The language of $\S 1$ of the Federal Trade Commission Act specifying three causes for removal from office, upon which the Supreme Court in part relied in Humphrey's Executor v. United States, 295 U. S. 602 (1934), does not appear in the Securities and Exchange Act of 1934. In the event that the President should be held to have no rightful authority to remove a Commissioner for personal reasons or reasons of policy, resignation could very probably be obtained through practical rather than legal steps.

The Interstate Commerce Commission affords no proper analogy. Its eleven members hold office for longer terms (seven years) and its status as an independent agency is established. 4 Sharfman, The Interstate Commerce Commission (1937) 11, 254-274. 
and trustees participate together. ${ }^{168}$ If the Commission should render its resources of experience and expert personnel available for a study of the modern indenture, with a view to perfecting its form and improving its protective features, such work would receive most interested cooperation and would have profound influence. No one is satisfied with the usual indenture of the present day. Its abbreviation and clarification is earnestly to be desired. Lawyers and business men alike would welcome the appearance of simple, standard clauses adapted to achieve the various indenture purposes. If the Commission were to recommend such provisions, framed after careful study and consultation, the authority of its recommendation would assure that the suggestions would be considered by every draftsman, and, so far as they proved valuable, widely adopted. Here is a way in which the unique resources of a federal agency could be of great assistance, without any of the risks of concentrated authority or unwise regulation.

An alternative, more appealing to those who feel positive action to be necessary, would be a simple statute directed to the major points of weakness. ${ }^{159}$ It is not within the scope of this article to offer in detail a statutory remedy, but it may be proper to suggest what can be attained by statutory means while yet avoiding some of the major difficulties which have been discussed.

It would be possible, and desirable, to provide by statute that indentures which could be reached, as the Barkley Bill reaches them, by the commerce and mail powers, should be required to have at least one corporate trustee. It would be equally feasible to provide that trustees under such issues should be registered with the Securities and Exchange Commission, and that their registration could be revoled, and their resignation necessitated, if it were established that conflict of interest had actually affected adversely the conduct of their trust; but this determination should be subject to review, both as to law and as to facts, by the Federal courts. Such review would be essential as a check upon arbitrary action.

Relief from the extremes of exculpatory clauses, and some needed sifting of the law concerning them, could be obtained if the statute were to include a further provision that after a default in the payment of interest or principal, and the expiration of a specified maximum grace period, the trustee should be liable for negligent conduct. There is precedent for such statutory procedure. ${ }^{100}$ It could be used with respect to

158. This was strongly urged as a solution at the House subcommittee's hearing. House Hearing 45, 46.

159. See testimony of $\mathrm{O}$. W. Haussermann, House He.rars 79-80, in which this suggestion, in somewhat different form, was made.

160. See, e.g., Uniforar Conditional Sales Act; N. Y. Decenent Estate Law, $\S 125$ [L. 1936, c. 378, as amended by L. 1938, c. 392] ; the Cummins-Carmacl amendment to the Interstate Commerce Act [34 Stat. 593, as amended by 44 Stat. 835, 44 Stat. 1448 and 46 Stat. 251, 49 U. S. C. $\$ 20(11)]$; Cassels, supra note 29, at 1; cf. Lond Sr. 
other parts of an indenture, ${ }^{101}$ but it should be sparingly used, and not invoked unless Congress should be convinced that a particular extension would be unquestionably desirable. If the original statute were restricted to the single matter of negligence after default, it is at least reasonably probable that any later extension, without the pressure of the whole regulatory legislation urging it forward, would receive the careful and nonpolitical consideration which is so clearly necessary.

The measure could stop with these provisions. It would not be the inclusive remedial legislation which the Barkley Bill is, in potentiality, but it would have some real force and further admonitory influence. It would have the advantage of definiteness, and indentures could be drawn in accordance with its terms in any part of the nation without the need of sending a representative to confer in Washington. It would not commit the solution of very difficult and important problems to administrative officers, including the unknown appointees of the future, with a right to exercise unlimited discretion. It would have the important virtte of moderation.

This suggestion assumes the reasonable cooperation of obligors, underwriters and trustees. It assumes that all share an immediate interest in perfecting the indenture as an instrument for the financing of modern business. It is not advanced upon the supposition that the partners to an indenture will inevitably seek to employ deceitful means to pervert the method or strip the investor of protection. It does not comport with the belief that if any reform is to be achieved the whole possible extent of reform must be swept through at once on the flood tide. These qualifications may limit its effect; they do render it inconsistent with some contemporary thought. But it is sincerely believed that the best consideration of these problems may be attained by detachment from contemporary thought, and by concentration upon the business purpose which the corporate indenture serves. If the law which has grown up about this instrument hampers it, legislation may be helpful, to liberate but not to restrict. Indenture securities have earned a place in the national economy, and the first concern of courts and legislatures should be to keep their place secure.

LEONARD's ACt (1859) 22 \& 23 VICT. c. $35 \$ 31$, repealed and replaced by Trustee ACT (1893) $56 \& 57$ Vict. c. $53 \$ 24$, repealed by 15 GEo. V. (1925) c. 19,870 , sch. IL.

161. Some of the less controversial subjects, such as responsibility for recordation, are susceptible of similar treatment. 